\title{
The genus Simplicillium
}

\author{
De-Ping Wei ${ }^{1,2,3,4}$, Dhanushka N. Wanasinghe ${ }^{3,5}$, Kevin D. Hyde ${ }^{2,4}$, \\ Peter E. Mortimer ${ }^{3}$, Jianchu Xu ${ }^{3,5}$, Yuan-Pin Xiao ${ }^{2,6,7}$, \\ Chitrabhanu S. Bhunjun ${ }^{2,7}$, Chaiwat To-anun'
}

I Department of Entomology and Plant Pathology, Faculty of Agriculture, Chiang Mai University, Chiang Mai, 50200, Thailand 2 Center of Excellence in Fungal Research, Mae Fah Luang University, Chiang Rai 57100, Thailand 3 Key Laboratory for Plant Diversity and Biogeography of East Asia, Kunming Institute of Botany, Chinese Academy of Science, Kunming 650201, Yunnan, China 4 Mushroom Research Foundation, 128 M.3 Ban Pa Deng T. Pa Pae, A. Mae Taeng, Chiang Mai 50150, Thailand 5 World Agroforestry Centre, East and Central Asia, Kunming 650201, Yunnan, China 6 Engineering Research Center of Southwest BioPharmaceutical Resources, Ministry of Education, Guizhou University, Guiyang, Guizhou Province, 550025, China 7 School of Science, Mae Fah Luang University, Chiang Rai, 57100, Thailand

Corresponding author: Peter E. Mortimer (petermortimer@mac.com)

Academic editor: Cecile Gueidan | Received 6 July2019 | Accepted 9 September 2019 | Published 19 November 2019

Citation: Wei D-P, Wanasinghe DN, Hyde KD, Mortimer PE, Xu J-C, Xiao Y-P, Bhunjun CS, To-anun C (2019) The genus Simplicillium. MycoKeys 60: 69-92. https://doi.org/10.3897/mycokeys.60.38040

\begin{abstract}
Simplicillium species have a wide host range and an extensive distribution. Some species are associated with rusts, as well as other plant pathogenic fungi and play an important role in biological control. In this study, two specimens of Simplicillium were collected from Chiang Mai Province, Thailand. Simplicillium formicae sp. nov. was isolated from an infected ant and S. lanosoniveum from Ophiocordyceps unilateralis which is a new host record. Species were initially identified using ITS gene sequences and confirmed using morphology coupled with phylogenetic analyses of a combined nrLSU, nrSSU, TEF and RPB1 dataset. Simplicillium formicae differs from other species in the genus by the presence of flask-shaped synnemata and phialides with intercalary nodes. Simplicillium lanosoniveum resembles other collections of the species by its completely solitary, tapering phialides and globose to ellipsoidal conidia which adhere in a slimly head. A key to species of Simplicillium is also provided.
\end{abstract}

\section{Keywords}

new species, Thailand, ant fungi, taxonomy, phylogeny

Copyright De-PingWei et al. This is an open access article distributed under the terms of the Creative Commons Attribution License (CC BY 4.0), which permits unrestricted use, distribution, and reproduction in any medium, provided the original author and source are credited. 


\section{Introduction}

Zare and Gams (2001) introduced Simplicillium to accommodate four taxa including the type species $S$. lanosoniveum and three other species, S. lamellicola, S. obclavatum and S. wallacei. Simplicillium species were historically placed in Verticillium sect. Prostrata which was described by Gams (1971) for prostrate conidiophore-producing species. Later, most of the species of Verticillium sect. Prostrata were reported as members in Clavicipitaceae, based on molecular data (including SSU, LSU and ITS sequences), whereas Simplicillium species consistently formed a monophyletic group apart from the other described taxa in this family (Zare et al. 2000; Gams and Zare 2001; Sung et al. 2001; Zare and Gams 2001). Recently, Clavicipitaceae was divided into three families, based on multi-gene phylogenetic analyses and Simplicillium was assigned to Cordycipitaceae (Hypocreales, Hypocreomycetidae, Sordariomycetes) (Sung et al. 2007; Maharachchikumbura et al. 2016; Wijayawardene et al. 2018). Zare and Gams (2008) excluded Simplicillium wallacei from Simplicillium and transferred it to Lecanicillium due to the basal position being closer to the latter genus than to the former genus in the cladogram of ITS data. Subsequently, ten species viz. Simplicillium chinense (Liu and Cai 2012), S. aogashimaense, S. cylindrosporum, S. minatense, S. subtropicum, S. sympodiophorum (Nonaka et al. 2013), S. lanosoniveum var. tianjinensis (Dong et al. 2014), S. calcicola (Zhang et al. 2017), S. coffeanum (Gomes et al. 2018) and S. filiforme (Crous et al. 2018) were restricted to Simplicillium, based on the phylogenetic analyses of ITS sequence data and strong morphological evidence. Its sexual-asexual connection has been established with S. lanosoniveum linked to a Torrubiella sp. (Zare and Gams 2001).

Simplicillium species have a wide distribution and are considered as mammal and plant-parasitic, symbiotic, entomopathogenic, fungicolous and nematophagous fungi, as they have a broad spectrum of hosts and substrates, such as insects, plants, rusts, nematodes, human nails, canine tissues and mushrooms, Chroococcus sp., soil, freshwater, marine and terrene environments (Zare and Gams 2001; Guo et al. 2012; Liu and Cai 2012; Dong et al. 2014; Liang et al. 2016; Sun et al. 2019). Several studies have been shown that Simplicillium species have a high ecological and economical value for biocontrol and bioactive compounds (Takata et al. 2013; Yan et al. 2015; Hyde et al. 2019). For example, Simplicillium lanosoniveum can be a phytopathogen, causing brown spots and lesions on flowers (Chen et al. 2008) or a mycoparasite on soybean rust (Ward et al. 2012; Gauthier et al. 2014) or a pathogen on aphids and other phytopathogens (Chen et al. 2017) or an anti-Trichomonas vaginalis agent (Scopel et al. 2013). Simplicillium chinense can be a biological control agent against plant parasitic nematodes (Zhao et al. 2013; Luyen 2017). Simplicillium lamellicola can suppress plant bacterial diseases and grey mould diseases of tomato (Solanum lycopersicum) and ginseng (Panax ginseng) (Dang et al. 2014; Shin et al. 2017). Simplicillium obclavatum has the ability to produce multiple xylanases and endoglucanases that have the potential to be used in biofuels, animal feed and food industry applications (Roy et al. 2013). Bioactive compounds with anti-fungal and anti-bacterial profiles and pharma- 
ceutical exopolysaccharides have been isolated from S. lanosoniveum (Yu et al. 2013; Fukuda et al. 2014; Xing et al. 2016; Dong et al. 2018). Linear and cyclic peptides with anti-fungal and anti-viral properties have also been discovered from the secondary metabolites of S. obclavatum (Liang et al. 2016, 2017).

Recent studies have shown that Thailand supports an amazing fungal diversity with numerous new species that have the potential for biotechnological application (Hyde et al. 2018, 2019). In this study, we introduce a novel species, Simplicillium formicae from northern Thailand and a new record of $S$. lanosoniveum with evidence from a combination of molecular analyses and morphological characteristics to reserve a natural resource for future studies regarding biocontrol in the forestry, agricultural and pharmaceutical industries.

\section{Material and methods}

\section{Sample collection and isolation}

The Mushroom Research Centre (MRC) is a disturbed rainforest located in Chiang Mai Province, Thailand (Aung et al. 2008). The forest consists of various tall tree and lower shrubs. The climate of Chiang Mai is controlled by tropical monsoons and the weather is typically hot and humid with temperatures often close to or above $30{ }^{\circ} \mathrm{C}$. Frequent rain and thunder showers usually last from June to late October (Chiang Mai Buddy website: https://chiangmaibuddy.com/welcome-to-chiang-mai/weather-andclimate/, accessed 26.8.2019). Two ant fungi were found anchored to the underside of two different shrubby leaves in the forest at the Mushroom Research Centre. These two fresh specimens; HKAS 102459 and HKAS 102447 were collected and placed in plastic containers and transported to the laboratory for subsequent study. Interestingly, the ant fungus HKAS 102447 was already dead and was colonised by a saprobic fungus. The isolate MFLUCC 18-1385 was separated from this saprobe which occurred on the surface of specimen HKAS 102447 via single spore isolation. The isolate MFLUCC 18-1379 was separated from specimen HKAS 102459 by directly cultivating the hyphae which covered the surface of the ant host. These two isolates were cultured with potato dextrose agar (PDA, $1 \% \mathrm{w} / \mathrm{v}$ peptone) and incubated at room temperature $\left(25^{\circ} \mathrm{C}\right)$.

\section{Morphological studies}

For long-term deposit, these two specimens were dried with allochroic silica gel to protect them from contamination of opportunistic fungi and to retain the informative taxonomic characters. The macro-morphological characters were observed with a stereoscope (Olympus SZ61) and the micro-morphological features were examined with a compound microscope (Nikon ECLIPSE Ni). Important characteristics such as myce- 
lium, phialides and conidia were captured with a digital camera (Canon EOS 600D). Measurements of perithecia, synnemata, phialides and conidia were taken using the Tarosoft (R) Image Frame Work programme and the images used were processed with Adobe Photoshop CS3 Extended v. 10.0 (Adobe, San Jose, CA).

\section{DNA extraction, PCR amplification and sequencing}

DNA was extracted from fresh mycelium of isolates MFLUCC 18-1379 and MFLUCC 18-1385 and from stromal tissue of ant fungus HKAS 102447 (the host of isolate MFLUCC 18-1385) using a DNA extraction kit (Biospin Fungus Genomic DNA Extraction Kit, BioFlux, China), following the instructions of the manufacturer. Extracted DNA was stored at $4{ }^{\circ} \mathrm{C}$ for use in regular work and duplicated at $-20{ }^{\circ} \mathrm{C}$ for long-term storage. The internal transcribed spacer (ITS1-5.8S-ITS2, ITS) was amplified with primer ITS4 and ITS5 (White et al. 1990) and was used for individual gene phylogenetic analyses. The large subunit (LSU), small subunit rDNA (SSU), translation elongation factor 1-alpha gene (TEF1- $\alpha$ ) and RNA polymerase II largest subunit 1 (RPB1) were also amplified as described in Wei et al. (2018) and used for multi-gene phylogenetic analyses. The PCR products were sent to Sangon Company, Kunming City, Yunnan Province, China for sequencing using the above primers. Newly generated sequences, used in the study, were submitted to GenBank to be assigned their accession numbers.

\section{Sequence alignments and phylogenetic analyses}

The raw sequences were verified with Finch TV version 1.4.0 (Mccredden 2016) and assembled with BioEdit v. 7.0.9.1 (Hall 1999). Sequence data were downloaded from GenBank based on BLAST searches of ITS sequences and with reference to the recent publications (Table 1). Most Simplicillium species are lacking protein-coding genes, but ITS sequences are available for all the species that are useful in understanding the intraspecific relationships within Simplicillium (Liu and Cai 2012, Nonaka et al. 2013, Dong et al. 2014 and Crous et al. 2018). Therefore, phylogenetic analyses, based on ITS regions, were generated throughout Simplicillium for the primary identification. Multi-gene phylogenetic analysis of the combined SSU, LSU, TEF and RPB1 sequences from representative species in Hypocreales was afterwards performed to confirm the taxonomic placements of our isolates.

The generated sequences of each gene region were aligned separately with representative sequences using MAFFT v. 7 web server (http://mafft.cbrc.jp/alignment/ server) (Kuraku et al. 2013; Katoh et al. 2017). The uninformative gaps and ambiguous regions were manually removed and different gene regions were concatenated using BioEdit v. 7.0.9.1 (Hall 1999). The maximum Likelihood (ML) analyses was performed using RAxML-HPC2 on XSEDE (8.2.10) at CIPRES Science Gateway V. 3.3 (https://www.phylo.org/portal2/home.action), with default setting, except the boot- 
Table I. Strains and GenBank accession numbers from related references used in multi-gene tree.

\begin{tabular}{|c|c|c|c|c|c|c|c|}
\hline Taxon & Voucher no. & Host/substrate & SSU rRNA & LSUrRNA & tef 1 & rPb1 & Reference \\
\hline $\begin{array}{l}\text { Akanthomyces } \\
\text { tuberculata }\end{array}$ & OSC 111002 & Lepidoptera & DQ522553 & DQ518767 & DQ522338 & DQ522384 & Spatafora et al. (2007) \\
\hline $\begin{array}{l}\text { Aschersonia } \\
\text { badia }\end{array}$ & BCC 8105 & Scale insect & DQ522537 & DQ518752 & DQ522317 & DQ522363 & Spatafora et al. (2007) \\
\hline $\begin{array}{l}\text { Aschersonia } \\
\text { placenta }\end{array}$ & BCC 7957 & Scale insect & DQ522538 & DQ518753 & DQ522318 & DQ522364 & Spatafora et al. (2007) \\
\hline $\begin{array}{l}\text { Balansia } \\
\text { henningsiana }\end{array}$ & $\begin{array}{c}\text { GAM } \\
16112=\text { AEG96-27a }\end{array}$ & Panicum sp. & AY545723 & AY545727 & AY489610 & AY489643 & Spatafora et al. (2007) \\
\hline $\begin{array}{l}\text { Balansia } \\
\text { pilulaeformi S }\end{array}$ & AEG 94-2 & Poaceae & AF543764 & AF543788 & DQ522319 & DQ522365 & Spatafora et al. (2007) \\
\hline $\begin{array}{l}\text { Claviceps } \\
\text { fusiformis }\end{array}$ & ATCC 26019 & Poaceae & DQ522539 & U17402 & DQ522320 & DQ522366 & Spatafora et al. (2007) \\
\hline $\begin{array}{l}\text { Claviceps } \\
\text { paspall }\end{array}$ & ATCC 13892 & Poaceae & U32401 & U47826 & DQ522321 & DQ522367 & Spatafora et al. (2007) \\
\hline $\begin{array}{l}\text { Claviceps } \\
\text { purpurea }\end{array}$ & GAM 12885 & $\begin{array}{l}\text { Dactylis } \\
\text { glomerata }\end{array}$ & AF543765 & AF543789 & AF543778 & AY489648 & Spatafora et al. (2007) \\
\hline $\begin{array}{l}\text { Cordyceps } \\
\text { farinosa }\end{array}$ & OSC 111005 & $\begin{array}{l}\text { Lepidoptera } \\
\text { pupa }\end{array}$ & DQ522558 & DQ518773 & DQ522348 & DQ522394 & Spatafora et al. (2007) \\
\hline $\begin{array}{l}\text { Cordyceps } \\
\text { heteropo } \mathrm{d}_{\mathrm{a}}\end{array}$ & OSC 106404 & Cicada & AY489690 & AY489722 & AY489617 & AY489651 & Spatafora et al. (2007) \\
\hline $\begin{array}{l}\text { Cordyceps } \\
\text { militaris }\end{array}$ & OSC 93623 & Lepidoptera & AY184977 & AY184966 & DQ522332 & DQ522377 & Spatafora et al. (2007) \\
\hline $\begin{array}{l}\text { Cordyceps } \\
\text { ophioglossoideS }\end{array}$ & OSC 106405 & Elaphomyces sp. & AY489691 & AY489723 & AY489618 & AY489652 & Spatafora et al. (2007) \\
\hline $\begin{array}{l}\text { Cordyceps } \\
\text { pruinosa }\end{array}$ & ARSEF 5413 & $\begin{array}{l}\text { Iragoides } \\
\text { fasciata }\end{array}$ & AY184979 & AY184968 & DQ522351 & DQ522397 & Spatafora et al. (2007) \\
\hline $\begin{array}{l}\text { Cordyceps } \\
\text { scarabaeicola }\end{array}$ & ARSEF 5689 & $\begin{array}{l}\text { Scarabaeidae } \\
\text { pupa }\end{array}$ & AF339574 & AF339524 & DQ522335 & DQ522380 & Spatafora et al. (2007) \\
\hline $\begin{array}{l}\text { Cordyceps } \\
\text { tenuipes }\end{array}$ & OSC 111007 & $\begin{array}{l}\text { Lepidoptera } \\
\text { pupa }\end{array}$ & DQ522559 & DQ518774 & DQ522349 & DQ522395 & Spatafora et al. (2007) \\
\hline $\begin{array}{l}\text { Drechmeria } \\
\text { balanoideS }\end{array}$ & CBS 250.82 & Nematoda & AF339588 & AF339539 & DQ522342 & DQ522388 & Spatafora et al. (2007) \\
\hline $\begin{array}{l}\text { Drechmeria } \\
\text { gunnii }\end{array}$ & OSC 76404 & $\begin{array}{l}\text { Lepidoptera } \\
\text { larva }\end{array}$ & AF339572 & AF339522 & AY489616 & AY489650 & Spatafora et al. (2007) \\
\hline $\begin{array}{l}\text { Drechmeria } \\
\text { sinensi } \mathrm{S}\end{array}$ & CBS 567.95 & Nematoda & AF339594 & AF339545 & DQ522343 & DQ522389 & Spatafora et al. (2007) \\
\hline $\begin{array}{l}\text { Engyodontium } \\
\text { aranear } \mathbf{U M}\end{array}$ & CBS 309.85 & Spider & AF339576 & AF339526 & DQ522341 & DQ522387 & Spatafora et al. (2007) \\
\hline Epichloë typhina & ATCC 56429 & Festuca rubra & U32405 & U17396 & AF543777 & AY489653 & Spatafora et al. (2007) \\
\hline $\begin{array}{l}\text { Hypocrella } \\
\text { nectrioide } \mathbf{S}\end{array}$ & GJS 89-104 & Scale insect & U32409 & U47832 & DQ522347 & DQ522393 & Spatafora et al. (2007) \\
\hline $\begin{array}{l}\text { Hypocrella } \\
\text { schizostachyi }\end{array}$ & BCC 14123 & Scale insect & DQ522557 & DQ518771 & DQ522346 & DQ522392 & Spatafora et al. (2007) \\
\hline $\begin{array}{l}\text { Lecanicillium } \\
\text { antillanu } \mathrm{m}\end{array}$ & CBS 350.85 & Agaric & AF339585 & AF339536 & DQ522350 & DQ522396 & Spatafora et al. (2007) \\
\hline $\begin{array}{l}\text { Lecanicillium } \\
\text { lecanii }\end{array}$ & $\begin{array}{c}\text { CBS } 101247=\mathrm{IMI} \\
304807\end{array}$ & Coccus viridi $\mathbf{S}$ & AF339604 & AF339555 & DQ522359 & DQ522407 & Spatafora et al. (2007) \\
\hline $\begin{array}{l}\text { Lecanicillium } \\
\text { wallace }\end{array}$ & $\begin{array}{c}\text { CBS } 101237=I M I \\
331549\end{array}$ & Lepidoptera & & AY184967 & EF469073 & EF469102 & $\begin{array}{l}\text { Zare and Gams (2008); } \\
\text { Kouvelis et al. (2008) }\end{array}$ \\
\hline $\begin{array}{l}\text { Metacordyceps } \\
\text { chlamydosporia }\end{array}$ & CBS 101244 & Mollusca & DQ522544 & DQ518758 & DQ522327 & DQ522372 & Spatafora et al. (2007) \\
\hline $\begin{array}{l}\text { Metacordyceps } \\
\text { tail }\end{array}$ & ARSEF 5714 & Lepidoptera & AF543763 & AF543787 & AF543775 & DQ522383 & Spatafora et al. (2007) \\
\hline $\begin{array}{l}\text { Metapochonia } \\
\text { goniodes }\end{array}$ & CBS 891.72 & Nematoda & AF339599 & AF339550 & DQ522354 & DQ522401 & Spatafora et al. (2007) \\
\hline $\begin{array}{l}\text { Metarhizium } \\
\text { album }\end{array}$ & ARSEF 2082 & Cofana spectra & DQ522560 & DQ518775 & DQ522352 & DQ522398 & Spatafora et al. (2007) \\
\hline $\begin{array}{l}\text { Metarbizium } \\
\text { favoviride }\end{array}$ & ARSEF 2037 & $\begin{array}{l}\text { Nilaparvata } \\
\text { lugens }\end{array}$ & AF339580 & AF339531 & DQ522353 & DQ522400 & Spatafora et al. (2007) \\
\hline $\begin{array}{l}\text { Metarhizium } \\
\text { majus }\end{array}$ & ARSEF 3145 & $\begin{array}{c}\text { Oryctes } \\
\text { rhinocer } \mathbf{O}_{\text {s }}\end{array}$ & AF339579 & AF339530 & AF543774 & DQ522399 & Spatafora et al. (2007) \\
\hline
\end{tabular}




\begin{tabular}{|c|c|c|c|c|c|c|c|}
\hline Taxon & Voucher no. & Host/substrate & SSU rRNA & LSUrRNA & tef 1 & rPb1 & Reference \\
\hline $\begin{array}{l}\text { Myriogenospora } \\
\text { atrament } \mathbf{O}_{\text {sa }}\end{array}$ & AEG 96-32 & $\begin{array}{l}\text { Andropogon } \\
\text { virginICUS }\end{array}$ & AY489701 & AY489733 & AY489628 & AY489665 & Spatafora et al. (2007) \\
\hline $\begin{array}{l}\text { Ophiocordyceps } \\
\text { acicularis }\end{array}$ & OSC 128580 & Coleoptera & DQ522543 & DQ518757 & DQ522326 & DQ522371 & Araújo et al. (2018) \\
\hline $\begin{array}{l}\text { Ophiocordyceps } \\
\text { aphodii }\end{array}$ & ARSEF 5498 & Coleoptera & DQ522541 & DQ518755 & DQ522323 & & Araújo et al. (2018) \\
\hline $\begin{array}{l}\text { Ophiocordyceps } \\
\text { brunneipunctata }\end{array}$ & OSC 128576 & Coleoptera & DQ522542 & DQ518756 & DQ522324 & DQ522369 & Araújo et al. (2018) \\
\hline $\begin{array}{l}\text { Ophiocordyceps } \\
\text { irangiensiS }\end{array}$ & OSC 128577 & Ant & DQ522546 & DQ518760 & DQ522329 & DQ522374 & Araújo et al. (2018) \\
\hline $\begin{array}{l}\text { Ophiocordyceps } \\
\text { irangiensis }\end{array}$ & OSC 128578 & Ant & DQ522556 & DQ518770 & DQ522345 & DQ522391 & Araújo et al. (2018) \\
\hline $\begin{array}{l}\text { Ophiocordyceps } \\
\text { melolontha } \mathrm{e}\end{array}$ & OSC 110993 & $\begin{array}{l}\text { Scarabaeidae } \\
\text { larva }\end{array}$ & DQ522548 & DQ518762 & DQ522331 & DQ522376 & Araújo et al. (2018) \\
\hline $\begin{array}{l}\text { Ophiocordyceps } \\
\text { nutans }\end{array}$ & OSC 110994 & Stink bug & DQ522549 & DQ518763 & DQ522333 & DQ522378 & Araújo et al. (2018) \\
\hline $\begin{array}{l}\text { Ophiocordyceps } \\
\text { ravenelil }\end{array}$ & OSC 110995 & Phyllophaga sp. & DQ522550 & DQ518764 & DQ522334 & DQ522379 & Araújo et al. (2018) \\
\hline $\begin{array}{l}\text { Ophiocordyceps } \\
\text { sphecocephala }\end{array}$ & OSC 110998 & Wasp & DQ522551 & DQ518765 & DQ522336 & DQ522381 & Araújo et al. (2018) \\
\hline $\begin{array}{l}\text { Ophiocordyceps } \\
\text { stylophora }\end{array}$ & OSC 111000 & Elateridae grub & DQ522552 & DQ518766 & DQ522337 & DQ522382 & Araújo et al. (2018) \\
\hline $\begin{array}{l}\text { Ophiocordyceps } \\
\text { unilateraliS }\end{array}$ & OSC 128574 & Ant & DQ522554 & DQ518768 & DQ522339 & DQ522385 & Araújo et al. (2018) \\
\hline $\begin{array}{l}\text { Ophiocordyceps } \\
\text { variabilis }\end{array}$ & ARSEF 5365 & Diptera larva & DQ522555 & DQ518769 & DQ522340 & DQ522386 & Spatafora et al. (2007) \\
\hline $\begin{array}{l}\text { Rotiferophthora } \\
\text { angustispora }\end{array}$ & CBS 101437 & Rotifera & AF339584 & AF339535 & AF543776 & DQ522402 & Spatafora et al. (2007) \\
\hline $\begin{array}{l}\text { Simplicillium } \\
\text { calcicola }\end{array}$ & $\begin{array}{c}\text { LC5586 = } \\
\text { CGMCC } 3.17943\end{array}$ & Calcaire & KY883301 & KU746752 & KX855252 & & Spatafora et al. (2007) \\
\hline $\begin{array}{l}\text { Simplicillium } \\
\text { lamellicola }\end{array}$ & CBS 116.25 & $\begin{array}{l}\text { Agaricus } \\
\text { bispor } \mathbf{U}_{\mathrm{s}}\end{array}$ & AF339601 & AF339552 & DQ522356 & DQ522404 & Spatafora et al. (2007) \\
\hline $\begin{array}{l}\text { Simplicillium } \\
\text { lanosoniveum }\end{array}$ & CBS 704.86 & $\begin{array}{l}\text { Hemileia } \\
\text { vastatri } \mathbf{X}\end{array}$ & AF339602 & AF339553 & DQ522358 & DQ522406 & Spatafora et al. (2007) \\
\hline $\begin{array}{l}\text { Simplicillium } \\
\text { obclavat } \mathbf{U}_{\mathrm{m}}\end{array}$ & CBS 311.74 & $\begin{array}{c}\text { Air above } \\
\text { sugarcane filed }\end{array}$ & AF339567 & AF339517 & EF468798 & & Spatafora et al. (2007) \\
\hline $\begin{array}{l}\text { Tolypocladium } \\
\text { fractum }\end{array}$ & OSC 110990 & Elaphomyces sp. & DQ522545 & DQ518759 & DQ522328 & DQ522373 & Spatafora et al. (2007) \\
\hline $\begin{array}{l}\text { Tolypocladium } \\
\text { japonicum }\end{array}$ & OSC 110991 & Elaphomyces sp. & DQ522547 & DQ518761 & DQ522330 & DQ522375 & Spatafora et al. (2007) \\
\hline $\begin{array}{l}\text { Torrubiella } \\
\text { ratticaudata }\end{array}$ & ARSEF 1915 & Euophrys sp. & DQ522562 & DQ518777 & DQ522360 & DQ522408 & Spatafora et al. (2007) \\
\hline $\begin{array}{l}\text { Verticillium } \\
\text { epiphytum }\end{array}$ & CBS 384.81 & $\begin{array}{l}\text { Hemileia } \\
\text { vastatri }\left.\right|_{\mathrm{X}}\end{array}$ & AF339596 & AF339547 & DQ522361 & DQ522409 & Spatafora et al. (2007) \\
\hline
\end{tabular}

strap iterations were set to 1,000 and the substitution model set to GTRGAMMA + I (Miller and Blair 2009). Maximum Parsimony analysis (MP) was performed by PAUP v. 4.0b10 (Swofford 2002) with the heuristic search option and Tree-Bisection-Reconnection (TBR) branch-swapping algorithm for 1000 random replicates. Branches that have a minimum branch length of zero were collapsed. Gaps were treated as "missing" and starting tree(s) were generated via stepwise addition (Hillis and Bull 1993). Tree Length [TL], Consistency Index [CI], Retention Index [RI], Rescaled Consistency Index $[\mathrm{RC}]$ and Homoplasy Index $[\mathrm{HI}]$ ) were calculated for all parsimonious trees. For Bayesian analysis, the best models of each gene were selected under Akaike Information Criterion (AIC) employing MrModeltest v. 2.3 (Nylander et al. 2008) and 
PAUP v. 4.0b10 (Ronquist and Huelsenbeck 2003). Bayesian analysis was performed using MrBayes v. 3.1.2 (Rannala and Yang 1996; Zhaxybayeva and Gogarten 2002) to evaluate posterior probabilities (BYPP) with the Markov Chain Monte Carlo sampling (MCMC) method. Trees were sampled and printed to output at every 1000 generations. The first $25 \%$ of sampled trees were discarded as part of a burn-in procedure, the rest of the trees were used to create the consensus tree and the average standard deviation of split frequencies was set as 0.01 .

Phylogenetic trees were visualised with FigTree v1.4.0 (Rambaut 2006) and edited in Microsoft PowerPoint, then saved as a PDF format and finally altered to JPG format using Adobe Illustrator CS6 (Adobe Systems Inc., United States). The finalised alignments and trees were submitted in TreeBASE (http://www.treebase.org/), with submission ID 24238 (ITS) and 24240 (multi-gene).

\section{Results and discussion}

\section{Phylogenic analysis}

The combined four gene dataset comprised 60 taxa from three families (Cordycipitaceae, Ophiocordycipitaceae and Clavicipitaceae) (Table 1) with Cosmospora coccinea, Nectria cinnabarina, Ophionectria trichospora and Viridispora diparietispora as the outgroup taxa. The RAxML analysis of the combined dataset yielded a best scoring tree (Figure 1) with a final ML optimisation likelihood value of -39792.595439 . The alignment comprised 3469 total characters including gaps, of which 2077 were constant, 338 variable characters parsimony-uninformative and 1054 characters parsimony-informative. The Kishino-Hasegawa $(\mathrm{KH})$ test showed $\mathrm{CI}=0.281, \mathrm{RI}=0.527$, $\mathrm{RC}=0.148$ and $\mathrm{HI}=0.719$. The matrix had 1655 distinct alignment patterns, with $6.42 \%$ undetermined characters or gaps. Estimated base frequencies were as follows: $\mathrm{A}=0.241091, \mathrm{C}=0.260362, \mathrm{G}=0.272837, \mathrm{~T}=0.225710$; substitution rates $\mathrm{AC}=$ $0.985172, \mathrm{AG}=2.843760, \mathrm{AT}=0.887714, \mathrm{CG}=0.898140, \mathrm{CT}=6.284116, \mathrm{GT}$ $=1.000000$; gamma distribution shape parameter $\alpha=0.585080$. MrModeltest v. 2.3 imply that GTR+I+G is the best-fit model for LSU and RPB1, SYM+I+G for SSU and TEF sequences.

The ITS dataset comprised 49 taxa from all Simplicillium species that are currently available in GenBank (Figure 2) with Cordyceps militaris (CBS178.59) (Cordycipitaceae, Hypocreales) as the outgroup taxon. The RAxML analysis of the ITS dataset yielded a best scoring tree (Figure 2) with a final ML optimisation likelihood value of -3155.597177 . The alignment comprised 570 total characters including gaps, of which 346 were constant, 43 variable characters parsimony-uninformative and 181 characters parsimony-informative. The Kishino-Hasegawa $(\mathrm{KH})$ test showed $\mathrm{CI}=0.681$, RI $=0.856, \mathrm{RC}=0.583$ and $\mathrm{HI}=0.319$. The matrix had 283 distinct alignment patterns, with $6.45 \%$ undetermined characters or gaps. Estimated base frequencies were as follows: $\mathrm{A}=0.232003, \mathrm{C}=0.283823, \mathrm{G}=0.254774, \mathrm{~T}=0.229400$; substitution rates 


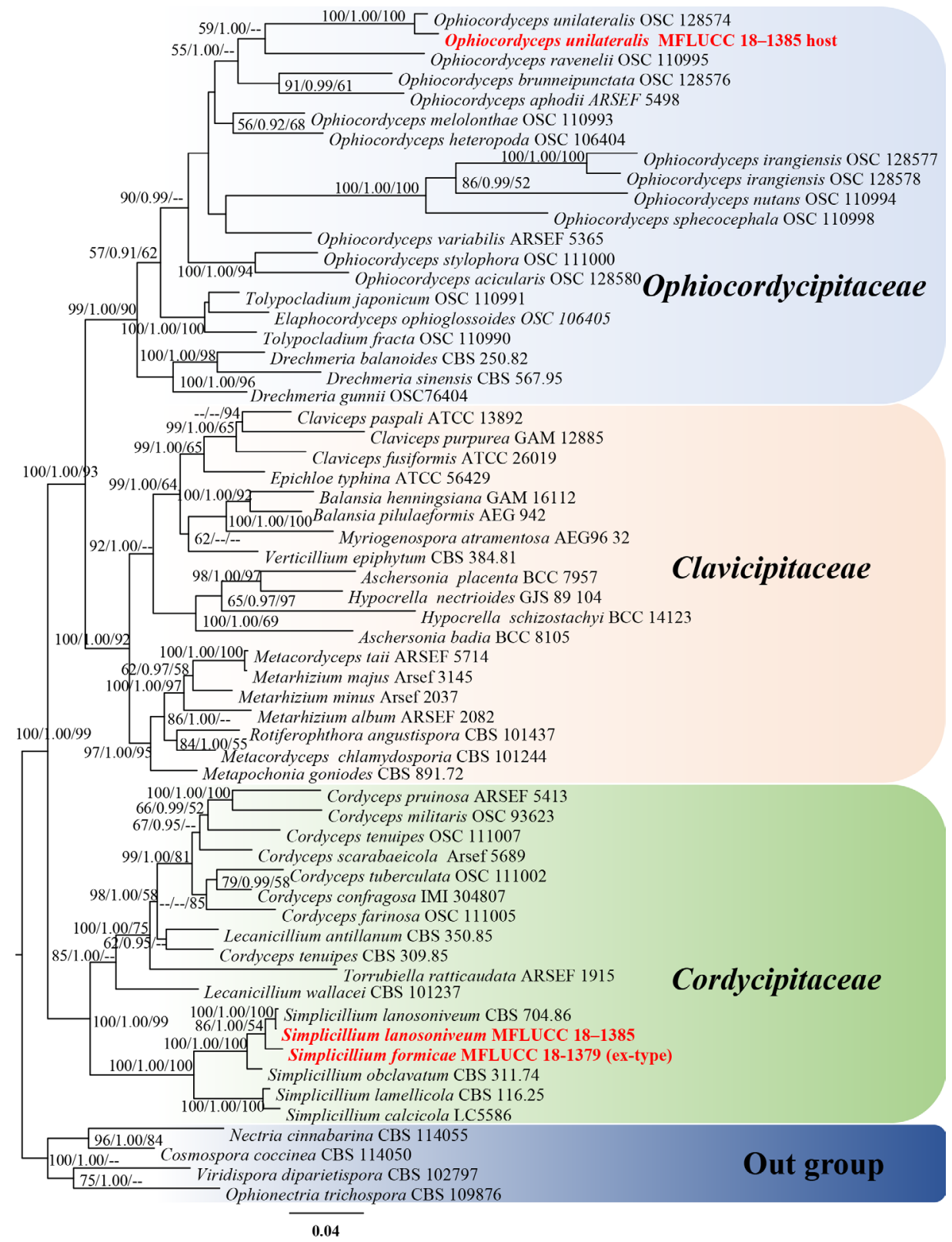

Figure I. Phylogram generated from maximum likelihood analysis based on combined SSU, LSU, TEF and RPB1 sequence data. Bootstrap values for maximum likelihood (ML, left) and maximum parsimony (MP, right) equal to or greater than $50 \%$ and Bayesian posterior probabilities (BYPP, middle) equal to or greater than 0.90 are placed nearby the note. The newly generated sequences are indicated in red bold.

$\mathrm{AC}=2.623562, \mathrm{AG}=2.645665, \mathrm{AT}=2.248749, \mathrm{CG}=1.653083, \mathrm{CT}=5.842034$, $\mathrm{GT}=1.000000$; gamma distribution shape parameter $\alpha=0.980038$. MrModeltest $\mathrm{v}$. 2.3 imply that GTR+I+G is the best-fit model for ITS sequences. 


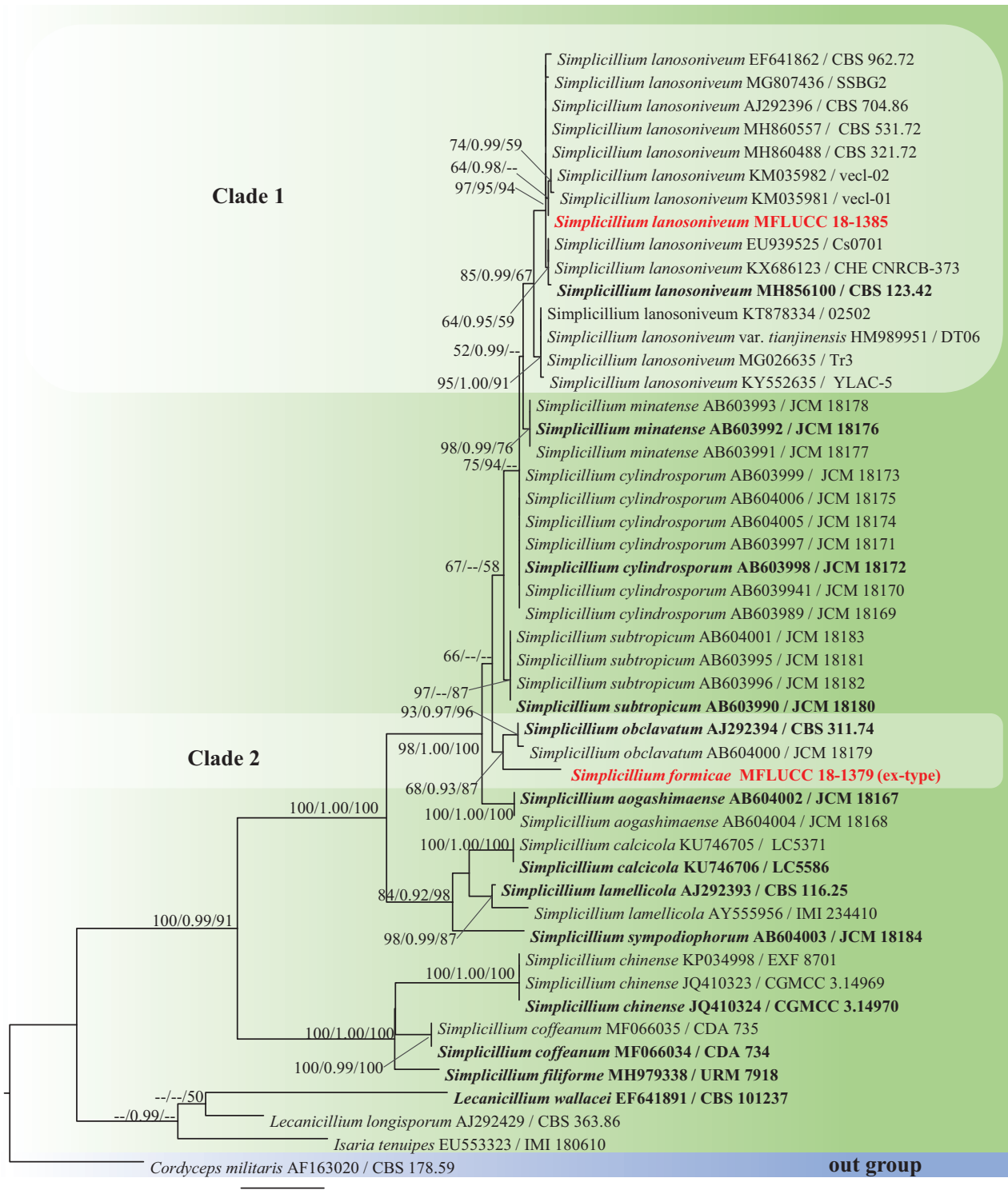

0.06

Figure 2. Phylogram generated from maximum likelihood analysis based on ITS sequence data. Bootstrap values for maximum likelihood (ML, left) and maximum parsimony (MP, right) equal to or greater than $50 \%$ and Bayesian posterior probabilities (BYPP, middle) equal to or greater than 0.90 are placed nearby the branches, respectively. The newly generated sequences are indicated in red bold and the type species are highlighted in black bold.

The multi-gene phylogenetic analyses showed that our isolates MFLUCC 181379 and MFLUCC 18-1385 grouped with the remaining Simplicillium species with strong support (100\% ML, 1.00 BYPP, 100\% MP, Figure 1) in Cordycipitaceae. The host of isolate MFLUCC 18-1385 grouped with Ophiocordyceps unilateralis (OSC 
128574) in Ophiocordycipitaceae with a significant statistical support (100\% ML, 1.00 BYPP, 100\% MP, Figure 1). In the individual ITS-based phylogenetic tree, the isolate MFLUCC 18-1379 constituted a close affiliation to Simplicillium obclavatum with moderate bootstrap support (68\% ML, 0.93 BYPP, 87\% MP, Figure 2, clade 2). The fungal isolate MFLUCC 18-1385 grouped with the remaining Simplicillium lanosoniveum strains with 85\% ML, 0.99 BYPP and 67\% MP support (Figure 2, clade 1).

\section{Taxonomy}

\section{Simplicillium W. Gams \& Zare, Nova Hedwigia 73(I-2): 38 (200I)}

Hyperparasitic on rusts or parasitic on nematodes or occurring in soil. Asexual morph: Mycelium thin, hyaline, septate, branched, smooth-walled. Phialides arising from prostrate aerial hyphae or rope-like and flask-shaped synnemata, typically solitary, rarely in whorls of 2-3, gradually tapering towards the apex, elongate, slender, smooth-walled, phialidic. Conidia hyaline, oval, spindle-shaped, cylindrical, subglobose to ellipsoidal, fusoid to filiform, straight to curved, smooth-walled. Conidia commonly form in small globose heads, sometimes in branched, unbranched, zigzag or imbricate chains, occasionally in sympodial proliferation with cylindrical conidium-bearing denticles. Colonies of species in this genus are usually fast growing, reaching $10-38 \mathrm{~mm}$ within 10 days on PDA, white, reverse brownish-cream to pale yellow, margin entire, cottony, fluffy or floccose. Some species produce yellow or orange pigment. Crystals are commonly present in the agar. Sexual morph: Torrubiella (Zare and Gams 2001; Liu and Cai 2012; Nonaka et al. 2013; Dong et al. 2014; Gomes et al. 2018; Zhang et al. 2017).

In this study, we introduce a new species and a new host species as described below.

\section{Simplicillium formicae D.P. Wei \& K.D. Hyde, sp. nov.}

Index Fungorum number: IF556432

Facesoffungi number: FoF 05813

Figure 3, 4

Etymology. the epithet refers to its host-ant.

Holotype. HKAS 102459; living culture: MFLUCC 18-1379.

Description. Parasitic on ant (Formicidae). Asexual morph: Hyphomycetous. Mycelium rarely septate, hyaline, smooth-walled, covering the whole body of the ant host. Synnemata $250-350 \times 65-100(\overline{\mathrm{x}}=300 \times 86, \mathrm{n}=10) \mu \mathrm{m}$, forming at the head region of ant host in circular arrangement, flask-shaped, hyaline to yellowish, composed of dense hyphae, somehow curved. Phialides $25-100 \times 0.5-1.5(\bar{x}=49 \times 1.1, \mathrm{n}=20) \mu \mathrm{m}$, arising from procumbent hyphae or synnemata, blastic, enteroblastic, phialidic, monophialidic, discrete, terminal, unbranched, solitary, aseptate, hyaline, smooth-walled, slender, occasionally a swollen node present. Conidia $2-3.5 \times 1.5-2.5(\bar{x}=2.6 \times 2$, 

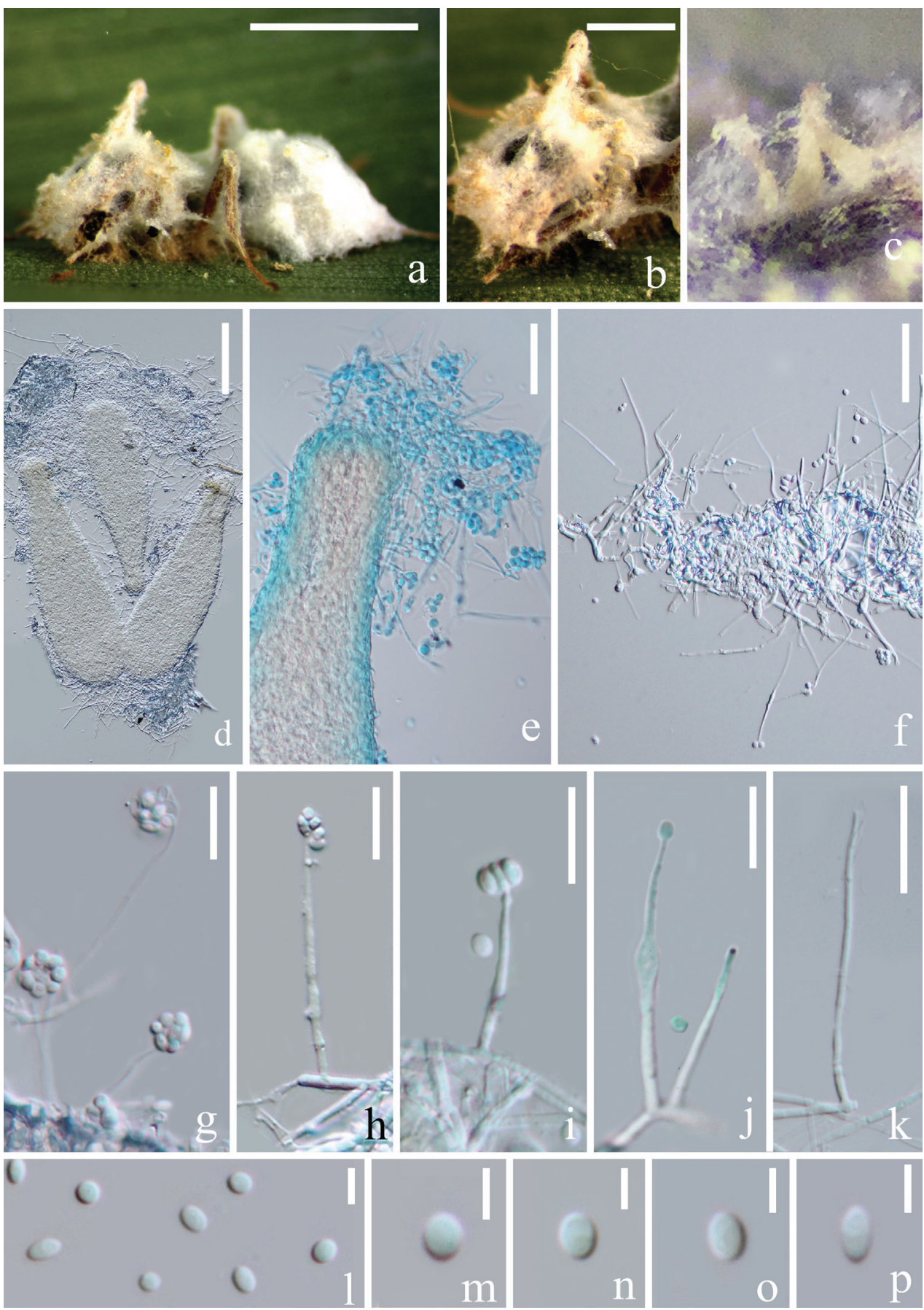

Figure 3. Simplicillium formicae (from HKAS 102459, holotype) a superficial hyphae associated with the ant host $\mathbf{b}-\mathbf{e}$ flask-shaped synnemata $\mathbf{f}-\mathbf{k}$ phialides bearing conidia $\mathbf{l}-\mathbf{p}$ conidia. Scale bars: $1000 \mu \mathrm{m}(\mathbf{a})$; $500 \mu \mathrm{m}$ (b); $100 \mu \mathrm{m}$ (d); $30 \mu \mathrm{m}(\mathbf{e}, \mathbf{f}) ; 15 \mu \mathrm{m}(\mathbf{j}, \mathbf{k}) ; 10 \mu \mathrm{m}$ (I-p) (e stained with cotton blue solution). 

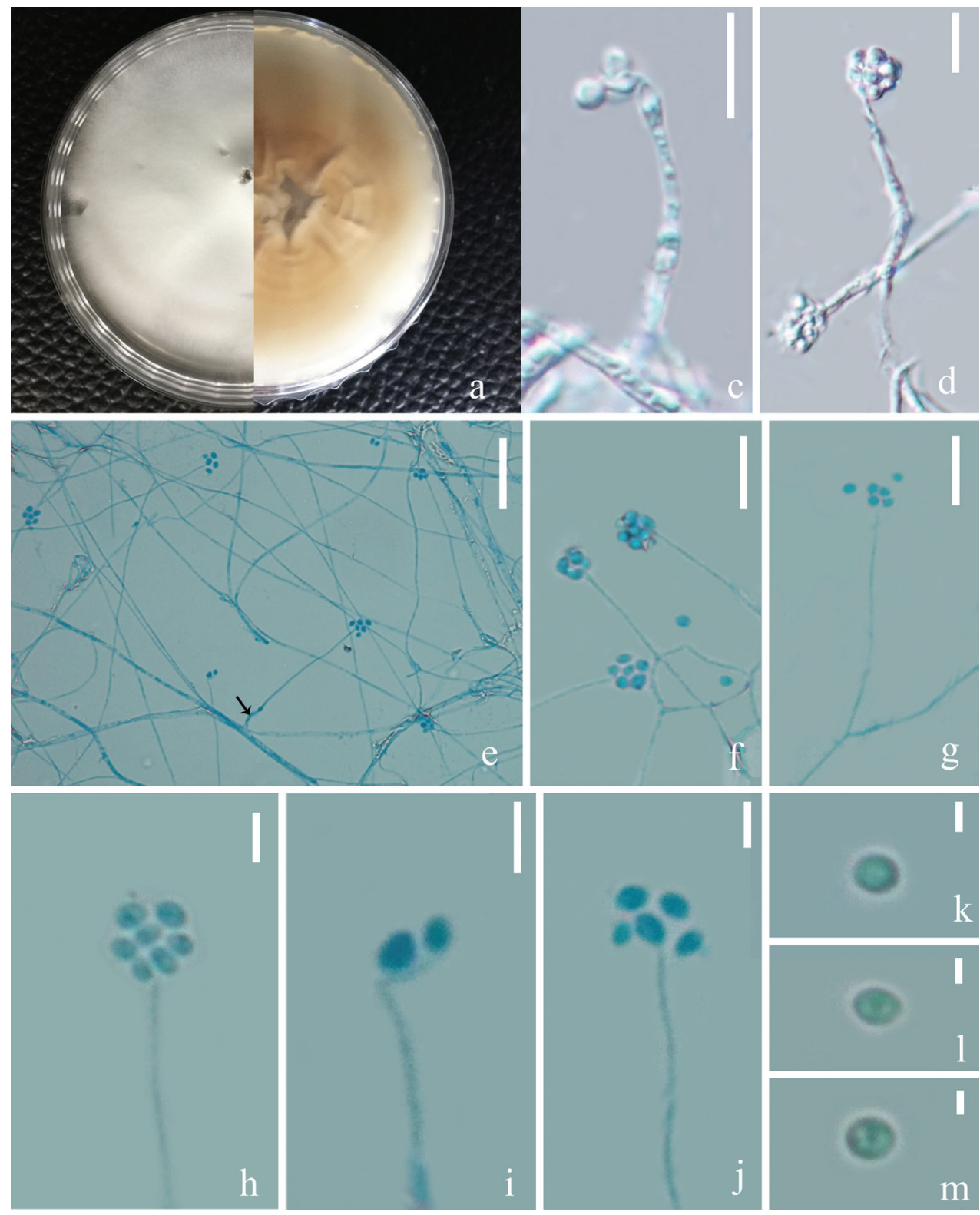

Figure 4. Simplicillium formicae (MFLUCC 18-1379, ex-type living culture) a upper and reverse view of cultures on PDA after 30 days $\mathbf{e}-\mathbf{g}$ phialides indicated with black arrow $\mathbf{c}, \mathbf{d}, \mathbf{h}-\mathbf{j}$ conidial mass on the tip of phialides $\mathbf{k}-\mathbf{m}$ conidia. Scale bars: $10 \mu \mathrm{m}(\mathbf{c}, \mathbf{d}, \mathbf{f}, \mathbf{g}) ; 20 \mu \mathrm{m}(\mathbf{e}) ; 3 \mu \mathrm{m}(\mathbf{h}-\mathbf{j}) ; 1 \mu \mathrm{m}(\mathbf{k}-\mathbf{m})(\mathbf{e}-\mathbf{j}$ stained with cotton blue solution).

$\mathrm{n}=30) \mu \mathrm{m}$, globose to ellipsoidal, hyaline, one-celled, smooth-walled, round at both ends, adhering in slimy head on the tip of phialides. Sexual morph: Undetermined.

Culture characteristics. The colonies were rapid-growing on PDA medium, reaching a diameter of $2.5-3(\overline{\mathrm{x}}=2.6, \mathrm{n}=9) \mathrm{cm}$, in 13 days at $22^{\circ} \mathrm{C}$, entire margin, circu- 
lar, velvety and white from above, with radial crack and primrose-yellow on reverse. In vitro, Synnemata absent. Phialides $25-75 \times 0.4-0.6(\overline{\mathrm{x}}=50 \times 0.55, \mathrm{n}=10) \mu \mathrm{m}$, arising from procumbent hyphae, blastic, enteroblastic, phialidic, discrete, terminal, unbranched, solitary, aseptate, hyaline, smooth-walled, relatively slender and long. Conidia $1.5-3 \times 1.5-2.5(\overline{\mathrm{x}}=2.3 \times 1.7, \mathrm{n}=100) \mu \mathrm{m}$, hyaline, globose to ellipsoidal, aseptate, smooth-walled, slightly guttulate, adhering in slimy head on the tip of phialides.

Material examined. THAILAND, Chiang Mai Province, Mushroom Research Centre, on an adult ant, 1 April 2018, Deping Wei, MRC18040102 (bolotype: HKAS 102459; ex-type living culture: MFLUCC 18-1379). Sequences generated from this strain have been deposited in GenBank with accession numbers: SSU $=$ MK765046, $\mathrm{LSU}=\mathrm{MK766512}$, ITS $=$ MK766511, TEF $=$ MK926451, RPB1 $=$ MK882623.

Note. Isolate MFLUCC 18-1379 has a close phylogenetic relationship with Simplicillium obclavatum, based on ITS sequence analysis. The new isolate is similar to Simplicillium obclavatum in terms of shape and dimensions of the conidia with slender phialides tapering towards the apex. However, they have a different conidial arrangement, by Simplicillium obclavatum having short-imbricate chains, whereas the new fungus has subglobose to globose head. There are numerous synnemata in a circular arrangement which can be observed in our isolate and those are absent in Simplicillium obclavatum. The comparisons of ITS sequences between our isolate MFLUCC 18-1379 and ex-type strain of Simplicillium obclavatum (CBS 311.74) show 23 bp differences within 550 bp (4.2\%). Thereby, we identify our isolates as a new species according to Jeewon and Hyde (2016).

\section{Simplicillium lanosoniveum (J.F.H. Beyma) Zare \& W. Gams, Nova Hedwigia 73(1-2): 39 (2001)}

Facesoffungi number: FoF 05814

Index Fungorum number: 532459

Figure 5

Cephalosporium lanosoniveum J.F.H. Beyma, Antonie van Leeuwenhoek 8: 121 (1942) (Basionym)

Ex-type. Netherlands, on hair of Cibotium schiedei in greenhouse, 1942, F.H. van Beyma, CBS123.42.

Description. Saprophytic on Ophiocordyceps unilateralis. Asexual morph: Hyphomycetous. Mycelium aseptate, hyaline, smooth-walled. Phialides $20-40 \times 1.1-2(\overline{\mathrm{x}}=30$ $\times 1.6, \mathrm{n}=20) \mu \mathrm{m}$, arising from the prostrate mycelium, blastic, enteroblastic, phialidic, monophialidic, discrete, terminal, aseptate, hyaline, smooth-walled, solitary, tapering toward the apex. Conidia $2-4.5 \times 1-3(\overline{\mathrm{x}}=3 \times 1.8, \mathrm{n}=60) \mu \mathrm{m}$, hyaline, amerospores, globose to ellipsoidal, smooth-walled, adhering in globose to ellipsoidal head at the apex of phialides. Sexual morph: Undetermined.

Culture characters. The colonies on PDA medium were rapid-growing, reaching a diam. of $5.5 \mathrm{~cm}$ in 30 days at $22^{\circ} \mathrm{C}$, white, entire margin, velvety, with radial cracks and primrose-yellow on the reverse. 

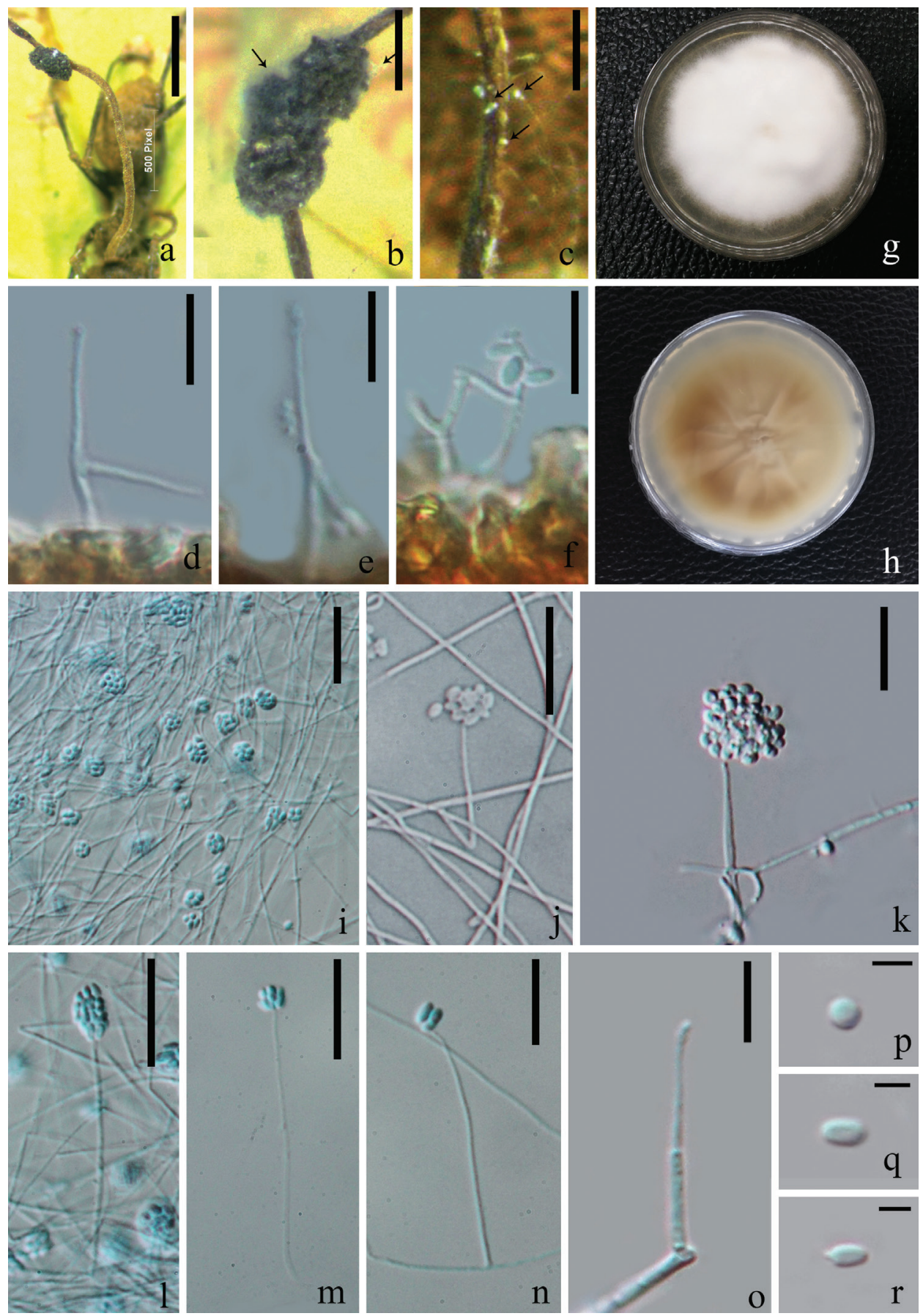

Figure 5. Simplicillium lanosoniveum (a-f from HKAS 102447, g-r from MFLUCC 18-1385) a host (Ophiocordyceps unilateralis); $\mathbf{b}, \mathbf{c}$ hyphae associated with host indicated with black arrows $\mathbf{g}, \mathbf{h}$ upper and reverse view of cultures on PDA after 40 days incubation $\mathbf{i}-\mathbf{I}$ conidial mass on the tip of phialides $\mathbf{m}-\mathbf{o}$ phialides bearing conidia $\mathbf{p}-\mathbf{r}$ conidia. Scale bars: $15 \mu \mathrm{m}(\mathbf{i}-\mathbf{m}) ; 10 \mu \mathrm{m}(\mathbf{d}-\mathbf{f}, \mathbf{n}, \mathbf{o}) ; 3 \mu \mathrm{m}(\mathbf{p}-\mathbf{r})$ (i, l-n stained with cotton blue solution). 
Host and distribution: Saprophytic on fungi, endophytic or symbiotic or pathogenic on plant, parasitic on rust, nematode and insect, occurring on soil, animal hair or human bronchoalveolar lavage fluid, with a cosmopolitan distribution (see Table 2).

Material examined. THAILAND, Chiang Mai Province, Mushroom Research Centre, on Ophiocordyceps unilateralis, 19 February 2018, Deping Wei, MRC18021901 (HKAS 102447; living culture: MFLUCC 18-1385). Sequences generated from this strain have been deposited in GenBank with accession numbers: SSU $=$ MK752791, $\mathrm{LSU}=\mathrm{MK752849}, \mathrm{ITS}=\mathrm{MK752683}, \mathrm{TEF}=\mathrm{MK} 926450, \mathrm{RPB} 1=\mathrm{MK} 882622$.

Note. Our isolate MFLUCC 18-1385 colonised on a decayed Ophiocordyceps unilateralis with white hyphae. In a thorough examination of the Ophiocordyceps unilateralis host, we found the phialides and conidia of our isolate grown on the surface of the host (Figure 5). Phylogenetically, our isolate grouped with the strains of Simplicillium lanosoniveum with high bootstrap support (85\% ML, 0.99 BYPP, 67\% MP, Figure 2). The nucleotides comparison between our isolate and the type strain of Simplicillium lanosoniveum (CBS123.42) showed only 5 bp differences out of 539 in the ITS region. This evidence proves that our isolate is a strain of $S$. lanosoniveum, according to Jeewon and Hyde (2016). Morphologically, it resembles S. lanosoniveum with solitary phialides without verticillate branches and conidia adhering on a slimy head. Most of the previous descriptions of this species were given in hand-drawings and scanning electron microscopy (SEM) patterns (Zare and Gams 2001; Ward et al. 2012; Gauthier et al. 2014). Simplicillium lanosoniveum has been reported from Enhalus acoroides (seagrass) in Trang Province, Thailand. In this study, we introduce our isolate MFLUCC 18-1385 as a new host record of Simplicillium lanosoniveum from Ophiocordyceps unilateralis and provide the updated morphological features for a better understanding of this species. Simplicillium lanosoniveum has been frequently reported as a hyperparasite of rust and plant pathogenic fungi. Therefore, this species has a high potential of being a natural source of microbial agents against microbiological diseases in commercial agriculture (Baiswar et al. 2014; Berlanga-Padilla et al. 2018). At first, we included all available sequences of S. lanosoniveum from GenBank in the individual gene tree. Some strains did not group with other strains but distributed throughout the genus in primary analyses (data not shown), so we excluded those strains from the final phylogenetic analysis. Most of the reported strains of $S$. lanosoniveum, including the invalid strains, are listed in Table 2 to show their distribution and host range, as well as the sequence data availability.

Ophiocordyceps unilateralis (Tul. \& C. Tul.) Petch, Trans. Br. mycol. Soc. 16(1): 74 (1931)

Index Fungorum number: 281145;

Facesoffungi number: FoF 05815

Figure 6

Description. Parasitic on ants (Formicidae). Sexual morph: Stromata up to $14 \mathrm{~mm}$ in length, $0.5 \mathrm{~mm}$ wide in the broadest part, cylindrical, brown, slightly tapering towards the apex, single, piercing through the dorsal neck region of the ant host. 
Table 2. Distribution, host and available sequence data of Simplicillium lanosoniveum strains.

\begin{tabular}{|c|c|c|c|c|c|c|}
\hline Species & Strain no. & Host and habitat & Origln & $\begin{array}{c}\text { Available gene } \\
\text { regíon }\end{array}$ & $\begin{array}{c}\text { Morphological } \\
\text { description }\end{array}$ & Reference \\
\hline \multirow[t]{27}{*}{ S. lanoson $\left.\right|_{\text {veum }}$} & CBS123.42 & $\begin{array}{l}\text { Hair of Cibotium } \\
\text { schiedei (Plant) }\end{array}$ & Netherland & ITS, LSU & & $\begin{array}{c}\text { GenBank; Zare } \\
\text { and Gams (2001) }\end{array}$ \\
\hline & $\mathrm{Cs} 0701$ & $\begin{array}{l}\text { Salvinia molesta } \\
\text { (Plant) }\end{array}$ & Taiwan & ITS & $\sqrt{ }$ & Chen et al. (2008) \\
\hline & \begin{tabular}{|l|} 
PSU-ES104 \\
\end{tabular} & $\begin{array}{c}\begin{array}{c}\text { Enhalus acoroides } \\
\text { (Plant) }\end{array} \\
\end{array}$ & $\begin{array}{c}\text { Trang Province, } \\
\text { Thailand }\end{array}$ & ITS & & $\begin{array}{l}\text { Supaphon et al. } \\
\left(201_{4}\right)\end{array}$ \\
\hline & CBS 531.72 & \begin{tabular}{|c|} 
Salvinia \\
rotundifolia (Plant)
\end{tabular} & USA & ITS & & $\begin{array}{l}\text { Zare and Gams } \\
\text { (2001) }\end{array}$ \\
\hline & $\operatorname{Tr} 3$ & \begin{tabular}{|c|}
$\begin{array}{c}\text { Salvia miltiorrhiza } \\
\text { (Plant) }\end{array}$ \\
\end{tabular} & China & ITS & & GenBank \\
\hline & YLAC-5 & $\begin{array}{c}\text { Endophytic on } \\
\text { Inula aconitum } \\
\text { (Plant) }\end{array}$ & China & ITS & & GenBank \\
\hline & & $\begin{array}{l}\text { Endophytic on } \\
\text { seaweed (Plant) }\end{array}$ & India & SSU & & GenBank \\
\hline & E1, E3, E5 & $\begin{array}{l}\text { Endophytes } \\
\text { of Sophora } \\
\text { alopecuroides } \\
\text { (Plant) } \\
\end{array}$ & Ningxia, China & SSU, ITS & $\sqrt{ }$ & Yu et al. (2013) \\
\hline & GA-B1 & $\begin{array}{l}\text { Grewia asiatica } \\
\text { (Plant) }\end{array}$ & $\begin{array}{c}\text { Shivalik region, } \\
\text { Jammu, India }\end{array}$ & SSU & & GenBank \\
\hline & IMI 303103b & $\begin{array}{c}\text { Hemileia vastatrix } \\
\text { (Rust) }\end{array}$ & Colombia & ITS, SSU & & $\begin{array}{l}\text { Zare and Gams } \\
\text { (2001), Kouvelis } \\
\text { et al. (2008) }\end{array}$ \\
\hline & AMH 9654 & $\begin{array}{c}\text { Rust pustules on } \\
\text { leaves of Elaeagnus } \\
\text { sp. }\end{array}$ & India & LSU, ITS & $\sqrt{ }$ & $\begin{array}{l}\text { Baiswar et al. } \\
\quad(2014)\end{array}$ \\
\hline & D082307-2A & Soybean rust & Louisiana & ITS & $\sqrt{ }$ & Ward et al. (2011) \\
\hline & vecl-02 & $\begin{array}{l}\text { Rust of Eleagnus } \\
\text { latifolia }\end{array}$ & India & ITS & & GenBank \\
\hline & vecl-01 & $\begin{array}{l}\text { Rust of Eleagnus } \\
\text { latifolia }\end{array}$ & India & ITS & & GenBank \\
\hline & CBS 704.86 & $\begin{array}{c}\begin{array}{c}\text { Hemileia vastatrix } \\
\text { (Rust) }\end{array} \\
\end{array}$ & Venezuela & $\begin{array}{l}\text { ITS, SSU, LSU, TEF, } \\
\text { RPB1, RPB2, ATP }\end{array}$ & $\sqrt{ }$ & $\begin{array}{c}\text { GenBank; Zare et } \\
\text { al. (2000) }\end{array}$ \\
\hline & S-599 & $\begin{array}{c}\text { Coleosporium } \\
\text { plumeriae (Rust) }\end{array}$ & \begin{tabular}{|c|} 
Campos dos \\
Goytacazes, GJ, \\
Brazil \\
\end{tabular} & ITS & & $\begin{array}{c}\text { Berlanga-Padilla et } \\
\text { al. (2018) }\end{array}$ \\
\hline & \begin{tabular}{|c|} 
D082307-2A- \\
GFP15 \\
\end{tabular} & $\begin{array}{c}\text { Phakopsora } \\
\text { pachyrbizi (Rust) }\end{array}$ & Florida, USA & & $\sqrt{ }$ & $\begin{array}{c}\text { Gauthier et al. } \\
(2014)\end{array}$ \\
\hline & $\begin{array}{c}\text { HKAS } \\
102447\end{array}$ & $\begin{array}{l}\text { Ophiocordyceps } \\
\text { unilaterglis } \\
\text { (Fungi) }\end{array}$ & $\begin{array}{c}\text { Chiang Mai, } \\
\text { Thailand }\end{array}$ & $\begin{array}{l}\text { SSU, LSU, ITS, } \\
\text { TEF, RPB } 1\end{array}$ & $\sqrt{ }$ & This study \\
\hline & TYLOO1 & $\begin{array}{c}\text { Pseudaulacaspis } \\
\text { pentagona (Insect) }\end{array}$ & $\begin{array}{c}\text { Shanxi Province, } \\
\text { China }\end{array}$ & ITS, SSU & $\sqrt{ }$ & $\begin{array}{l}\text { Wang et al. } \\
\text { (2016) }\end{array}$ \\
\hline & SSBG2 & $\begin{array}{c}\text { Coccus hesperidum } \\
\text { (Insect) }\end{array}$ & \begin{tabular}{|c|} 
The South- \\
Siberian \\
Botanical \\
Garden, Russia \\
\end{tabular} & ITS & $\sqrt{ }$ & $\begin{array}{l}\text { Skaptsov et al. } \\
\text { (2017) }\end{array}$ \\
\hline & TAMA 173 & $\begin{array}{l}\text { Aphidoidea sp. } \\
\text { (Insect) }\end{array}$ & Ibaraki, Japan & ITS & & $\begin{array}{l}\text { Fukuda et al. } \\
\text { (2014) }\end{array}$ \\
\hline & $\begin{array}{c}\text { CHE- } \\
\text { CNRCB } 373 \\
\end{array}$ & $\begin{array}{l}\text { Diaphorina citri } \\
\text { (Insect) }\end{array}$ & Colima, USA & ITS & & $\begin{array}{c}\text { Berlanga-Padilla et } \\
\text { al. (2018) }\end{array}$ \\
\hline & ARSEF 8822 & Culicid (Insect) & Tanzania & & & $\begin{array}{c}\text { Hubner-Campos } \\
\text { et al. (2013) }\end{array}$ \\
\hline & ARSEF7550 & Coccoidea (Insect) & Brazil & TEF & & GenBank \\
\hline & 1T9BA & Tick (Insect) & New York, USA & ITS & & $\begin{array}{c}\text { Greengarten et al. } \\
(2011)\end{array}$ \\
\hline & Btab03 & $\begin{array}{l}\text { Bemisia tabaci } \\
\text { (Insect) }\end{array}$ & South Korea & ITS & & GenBank \\
\hline & $113-8$ & Mosquitoes (Insect) & Japan & ITS & & Ishii et al. (2015) \\
\hline
\end{tabular}




\begin{tabular}{|c|c|c|c|c|c|c|}
\hline Species & Strain no. & Host and habitat & Orig $\dot{I}_{n}$ & $\begin{array}{l}\text { Available gene } \\
\text { reglon }\end{array}$ & $\begin{array}{c}\text { Morphological } \\
\text { description }\end{array}$ & Reference \\
\hline \multirow[t]{6}{*}{ S. lanosoniveum } & $7 \mathrm{~S}$ & $\begin{array}{l}\text { Heterodera schachtii } \\
\text { (Nematode) }\end{array}$ & Iran & ITS & & GenBank \\
\hline & & $\begin{array}{c}\text { Hair of giant panda } \\
\text { (Animal) }\end{array}$ & China & ITS & & GenBank \\
\hline & 2502 & $\begin{array}{l}\text { Bronchoalveolar } \\
\text { lavage fluid } \\
\text { (Human) }\end{array}$ & China & ITS & & GenBank \\
\hline & $41559-3$ & Cave and mine & $\begin{array}{c}\text { New York State, } \\
\text { USA }\end{array}$ & ITS, LSU & & GenBank \\
\hline & CBS 321.72 & & Malaysia & SSU, LSU, ITS & & $\begin{array}{c}\text { Genbank; } \\
\text { Summerbell et al. } \\
(2011)\end{array}$ \\
\hline & CBS 322.72 & & Malaysia & ITS & & GenBank \\
\hline
\end{tabular}

Note: ' $V$ ' means related data are available. The strains collected from Thailand are indicated with black bold.
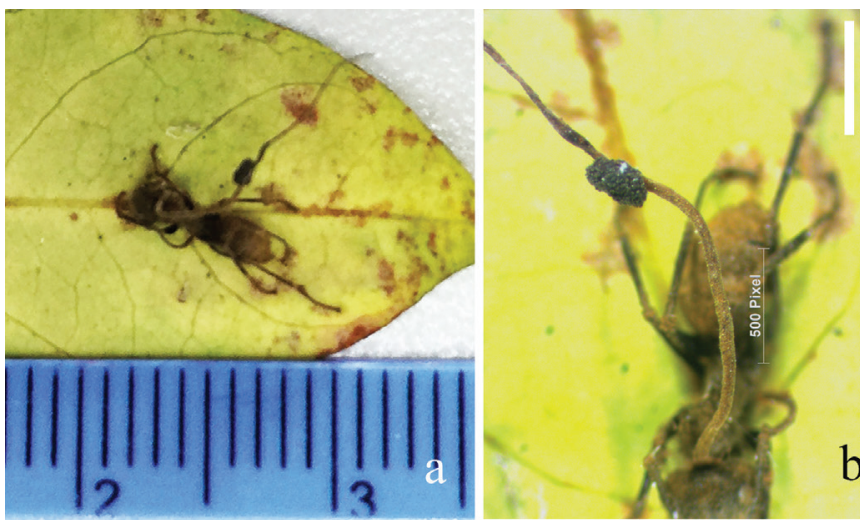

b

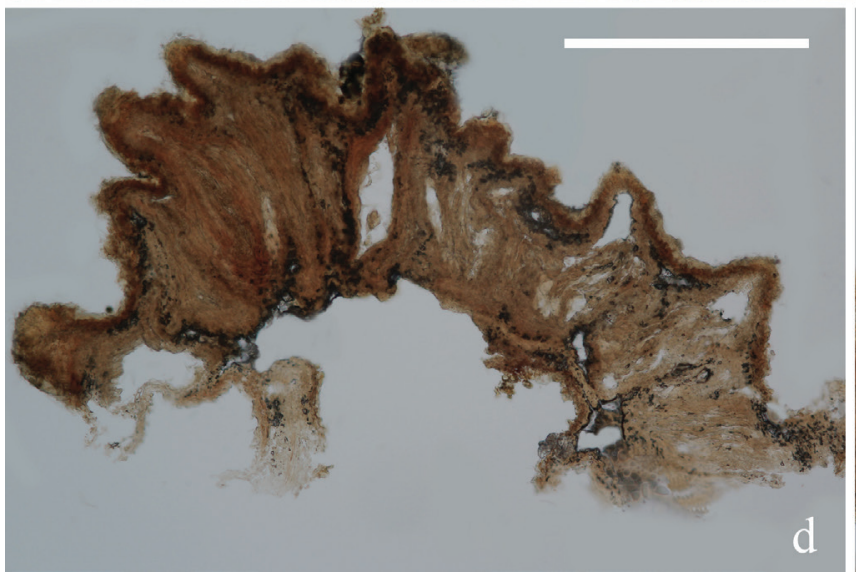

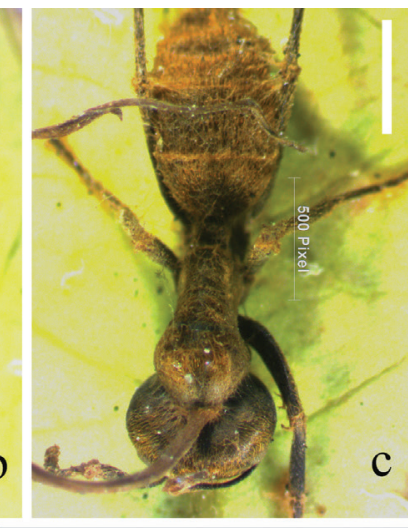

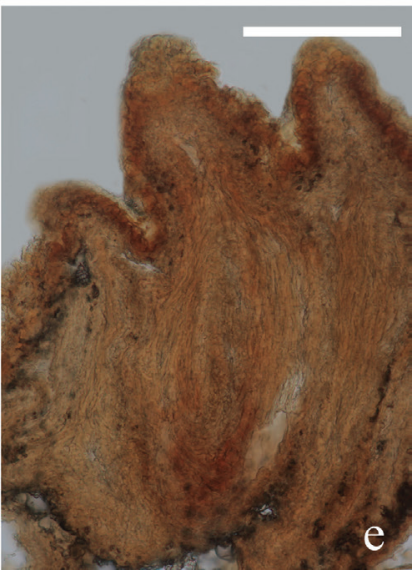

Figure 6. Ophiocordyceps unilateralis (from HKAS 102447) a stroma emerging from host b ascomata on stroma c host (Formicidae) d, e decayed perithecia. Scale bars: $500 \mu \mathrm{m}$ (b, c); $300 \mu \mathrm{m}(\mathbf{d}) ; 100 \mu \mathrm{m}(\mathbf{e})$.

Ascomatal cushion hemisphere, up to $1.2 \mathrm{~mm}$ in diam., laterally attaching to the erect stroma stalk, dark brown, with ostioles protruding from the cushions. Perithecia 200-400 × 50-120 ( $\overline{\mathrm{x}}=294 \times 81, \mathrm{n}=10) \mu \mathrm{m}$, sub-immersed, flask-shaped. Asci and ascospores were too old to observe their features. Asexual morph: Undetermined. 
Note. This collection was already decayed and was colonised by other fungi which we introduced as a new host record of Simplicillium lanosoniveum from Thailand. The outline of this specimen was intact, while its asci and ascospores were too old to analyse. We retrieved DNA through direct sequencing from the stromal tissue.

Sequences generated from this specimen have been deposited in GenBank with accession numbers: SSU $=$ MK752759, LSU $=$ MK752812, ITS $=$ MK752874. The herbarium material is deposited at KUN herbarium, Yunnan Province, China. In the multi-gene phylogenetic tree, this collection groups with Ophiocordyceps unilateralis (OSC 128574) with a strongly supported bootstrap value (100\% ML, 1.00 BYPP, $100 \%$ MP, Figure 1). Therefore, we identify this collection as O. unilateralis, based on its morphologic features and molecular evidence.

\section{Key to accepted species of Simplicillium}

1a Conidia formed in sympodia

S. sympodiophorum

1b Conidia solitary, borne on the tip of phialides......................... S. calcicole

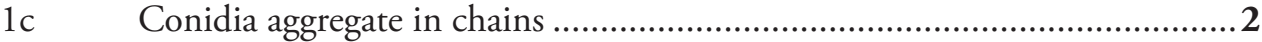

1d Conidia aggregate in subglobose to ellipsoidal heads ............................. 3

1e Conidia aggregate in globose heads ............................................... 4

2a Conidia 2.5-3.5 $\times 1-2 \mu \mathrm{m}$, obclavate to ellipsoidal, formed in short imbricate chains

S. obclavatum

2b Conidia 3.5-5.0 $\times 1.0-1.5 \mu \mathrm{m}$, oval, ellipsoidal or cylindrical, formed in vertical chains

S. chinense

2c Conidia 7.2-12.5 $\times 1 \mu \mathrm{m}$, long, fusiform to short filiform, hyaline, straight to curved, formed in vertical chains

S. filiforme

3a Phialides $15-50 \times 0.7-1.0 \mu \mathrm{m}$, colonies light to dark-brown reverse on PDA, usually with yellow pigment diffusing into the agar

S. lamellicola

3b Phialides 11-44 (-70) × 1.0-2.4 $\mu \mathrm{m}$, colonies cream-coloured reverse on PDA, no diffused pigment

S. coffeanum

4a Present flask-shaped synnemata..............................

S. formicae

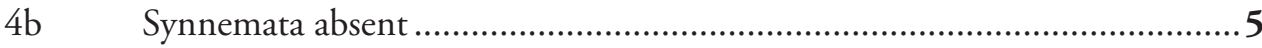

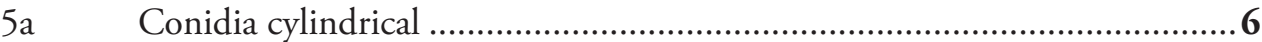

5b Conidia globose to subglobose or ellipsoidal ......................................... 7

6a Phialides $23-53 \times 1.2-2.0 \mu \mathrm{m}$, long .......................... S. cylindrosporum

6b Phialides $17-32 \times 1.2-2.0(-2.5) \mu \mathrm{m}$, short........................... aogashima

7a Phialides 35-75 × 1.2-3.0 $\mu \mathrm{m}$, conidia 4.5-6.0 $\times 2.5-3.5 \mu \mathrm{m}$, colonies light yellow to deep tawny in reverse view on PDA ... S. lanosoniveum var. tianjinensis

7b Phialides 15-39 $\times 0.7-1.9 \mu \mathrm{m}$, conidia 1.5-3 $\times 0.7-1.3 \mu \mathrm{m}$, colonies brownish-cream to pale yellow reverse on PDA.

S. lanosoniveum

7c Phialides 11-31(-47) × 1.0-1.7 $\mu \mathrm{m}$, conidia 2.0-3.5 × 1.8-2.5(-2.8) $\mu \mathrm{m}$, colonies brown reverse on PDA

S. minatense

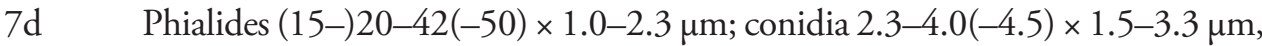
colonies brownish-orange to brown reverse on PDA

S. subtropicum 


\section{Conclusion}

A new species Simplicillium formicae and a new host record species Simplicillium lanosoniveum from Ophiocordyceps unilateralis were introduced, based on phylogenetic analyses and morphological evidence. The host and distribution of S. lanosoniveum was summarised and a key to Simplicillium was provided.

\section{Acknowledgements}

We are grateful to the Thailand Research Fund (TRF) grant no DBG6080013 entitled 'the future of specialist fungi in a changing climate: baseline data for generalist and specialist fungi associated with ants, Rhododendron species and Dracaena species" for its financial support. Dhanushka Wanasinghe would like to thank CAS President's International Fellowship Initiative (PIFI) for funding his postdoctoral research (number 2019 ${ }^{\mathrm{PC}} 0008$ ) and the 64th batch of China Postdoctoral Science Foundation (grant no.: Y913083271). Peter E. Mortimer and D.N. Wanasinghe thank the National Science Foundation of China and the Chinese Academy of Sciences for financial support under the following grants: 41761144055, 41771063 and Y4ZK111B01. We acknowledge the Kunming Institute of Botany for providing the laboratories and instruments for molecular work. We appreciate the Centre of Excellence in Fungal Research (Mae Fah Luang University) for providing the grant support for collecting trips. We thank Milan Samarakoon and Dr. Sajeewa Maharachchikumbura for their assistance with the phylogenetic analyses and Dr. Shaun Pennycook for his help with the nomenclature of the novel species.

\section{References}

Araújo JPM, Evans HC, Kepler R, Hughes DP (2018) Zombie-ant fungi across continents: 15 new species and new combinations within Ophiocordyceps. I. Myrmecophilous hirsutelloid species. Studies in Mycology 90: 119-160. https://doi.org/10.1016/j.simyco.2017.12.002

Aung OM, Soytong K, Hyde KD (2008) Diversity of entomopathogenic fungi in rainforests of Chiang Mai Province, Thailand. Fungal Diversity 30: 15-22.

Baiswar P, Ngachan S, Rymbai H, Chandra S (2014) Simplicillium lanosoniveum, a hyperparasite on Aecidium elaeagni-latifoliae in India. Australasian Plant Disease Notes 9(1): 144-149. https://doi.org/10.1007/s13314-014-0144-z

Berlanga-Padilla AM, Gallou A, Ayala-Zermeño MA, Serna-Domínguez MG, Montesinos-Matías R, Rodríguez-Rodríguez JC, Arredondo-Bernal HC (2018) Hongos entomopatógenos asociados a Diaphorina citri (Hemiptera: Liviidae) en Colima, México. Revista Mexicana de Biodiversidad 89(4): 986-1001. https://doi.org/10.22201/ ib.20078706e.2018.4.2334

Chen RS, Huang CC, Li JC, Tsay JG (2017) Evaluation of characteristics of Simplicillium lanosoniveum on pathogenicity to aphids and in vitro antifungal potency against plant pathogenic fungi. International Journal of Environmental \& Agriculture Research 3: 55-61. 
Chen RS, Huang CC, Li JC, Tsay GJ (2008) First report of Simplicillium lanosoniveum causing brown spot on Salvinia auriculata and S. molesta in Taiwan. Plant Disease 92(11): 1589-1589. https://doi.org/10.1094/PDIS-92-11-1589C

Crous PW, Luangsa-ard JJ, Wingfield MJ, Carnegie AJ, Hernandez-Restrepo M, Lombard L, Roux J, Barreto RW, Baseia IG, Cano-Lira JF, Martin MP, Morozova OV, Stchigel AM, Summerell BA, Brandrud TE, Dima B, Garcia D, Giraldo A, Guarro J, Gusmao LFP, Khamsuntorn P, Noordeloos ME, Nuankaew S, Pinruan U, Rodriguez-Andrade E, SouzaMotta CM, Thangavel R, Iperen AL, Abreu VP, Accioly T, Alves JL, Andrade JP, Bahram M, Baral HO, Barbier E, Barnes CW, Bendiksen E, Bernard E, Bezerra JDP, Bezerra JL, Bizio E, Blair JE, Bulyonkova TM, Cabral TS, Caiafa MV, Cantillo T, Colman AA, Conceicao LB, Cruz S, Cunha AOB, Darveaux BA, Silva AL, da Silva GA, da Silva GM, da Silva RMF, de Oliveira RJV, Oliveira RL, De Souza JT, Duenas M, Evans HC, Epifani F, Felipe MTC, Fernandez-Lopez J, Ferreira BW, Figueiredo CN, Filippova NV, Flores JA, Gene J, Ghorbani G, Gibertoni TB, Glushakova AM, Healy R, Huhndorf SM, Iturrieta-Gonzalez I, Javan-Nikkhah M, Juciano RF, Jurjevic Z, Kachalkin AV, Keochanpheng K, Krisai-Greilhuber I, Li YC, Lima AA, Machado AR, Madrid H, Magalhaes OMC, Marbach PAS, Melanda GCS, Miller AN, Mongkolsamrit S, Nascimento RP, Oliveira TGL, Ordonez ME, Orzes R, Palma MA, Pearce CJ, Pereira OL, Perrone G, Peterson SW, Pham THG, Piontelli E, Pordel A, Quijada L, Raja HA, de Paz ER, Ryvarden L, Saitta A, Salcedo SS, Sandoval-Denis M, Santos TAB, Seifert KA, Silva BDB, Smith ME, Soares AM, Sommai S, Sousa JO, Suetrong S, Susca A, Tedersoo L, Telleria MT, Thanakitpipattana D, Valenzuela-Lopez N, Visagie CM, Zapata M, Groenewald JZ (2018) Fungal planet description sheets: 785-867. Persoonia 41: 238-417. https://doi.org/10.3767/persoonia.2018.41.12

Dong QL, Dong RZ, Xing XY, Li YK (2018) A new antibiotic produced by the cyanobacterium-symbiotic fungus Simplicillium lanosoniveum. Natural Product Research 32(11): 1348-1352. https://doi.org/10.1080/14786419.2017.1343320

Dong QL, Lin TY, Xing XY, Chen B, Han Y (2014) Identification of a symbiotic fungus from blue-green alga and its extracellular polysaccharide. Letters in Applied Microbiology 58(4): 303-310. https://doi.org/10.1111/lam.12192

Dang LQ, Shin TS, Park MS, Choi YH, Choi GJ, Jang KS, Kim IS, Kim JC (2014) Antimicrobial Activities of Novel Mannosyl Lipids Isolated from the Biocontrol Fungus Simplicillium lamellicola BCP against Phytopathogenic Bacteria. Journal of Agricultural and Food Chemistry 62(15): 3363-3370. https://doi.org/10.1021/jf500361e

Fukuda T, Sudoh Y, Tsuchiya Y, Okuda T, Igarashi Y (2014) Isolation and biosynthesis of preussin B, a pyrrolidine alkaloid from Simplicillium lanosoniveum. Journal of Natural Products 77(4): 813-817. https://doi.org/10.1021/np400910r

Gams W (1971) Cephalosporium-artige Schimmelpilze (Hyphomycetes). Gustav Fischer Verlag, Stuttgart, 1-262.

Gams W, Zare R (2001) A revision of Verticillium sect. Prostrata. III. Generic classification. Nova Hedwigia 72: 329-337.

Gauthier NW, Maruthachalam K, Subbarao KV, Brown M, Xiao Y, Robertson CL, Schneider RW (2014) Mycoparasitism of Phakopsora pachyrhizi, the soybean rust pathogen, by Simplicillium lanosoniveum. Biological Control 76: 87-94. https://doi.org/10.1016/j.biocontrol.2014.05.008 
Gomes AAM, Pinho DB, Cardeal ZL, Menezes HC, De Queiroz MV, Pereira OL (2018) Simplicillium coffeanum, a new endophytic species from Brazilian coffee plants, emitting antimicrobial volatiles. Phytotaxa 333(2): 188-198. https://doi.org/10.11646/phytotaxa.333.2.2

Greengarten PJ, Tuininga AR, Morath SU, Falco RC, Norelus H, Daniels TJ (2011) Occurrence of soil- and tick-borne fungi and related virulence tests for pathogenicity to ixodes scapularis (Acari: Ixodidae). Journal of Medical Entomology 48(2): 337-344. https://doi. org/10.1603/ME09116

Guo RY, Zheng NN, Lu HF, Yin HF, Yao JM, Chen Y (2012) Increased diversity of fungal flora in the vagina of patients with recurrent vaginal candidiasis and allergic rhinitis. Microbial Ecology 64(4): 918-927. https://doi.org/10.1007/s00248-012-0084-0

Hall T (1999) BioEdit: a user-friendly biological sequence alignment editor and analysis program for windows 95/98/NT. Nucleic Acids Symposium Series 41(41): 95-98

Hillis DM, Bull JJ (1993) An empirical test of bootstrapping as a method for assessing confidence in phylogenetic analysis. Systematic Biology 42(2): 182-192. https://doi. org/10.1093/sysbio/42.2.182

Hubner-Campos RF, Leles RN, Rodrigues J, Luz C (2013) Efficacy of entomopathogenic hypocrealean fungi against Periplaneta Americana. Parasitology International 62(6): 517521. https://doi.org/10.1016/j.parint.2013.07.013

Ishii M, Takeshita J, Ishiyama M, Tani M, Koike M, Aiuchi D (2015) Evaluation of the pathogenicity and infectivity of entomopathogenic hypocrealean fungi, isolated from wild mosquitoes in Japan and Burkina Faso, against female adult Anopheles stephensi mosquitoes. Fungal Ecology 15: 39-50. https://doi.org/10.1016/j.funeco.2015.02.002

Hyde KD, Norphanphoun C, Chen J, Dissanayake AJ, Doilom M, Hongsanan S, Jayawardena RS, Jeewon R, Perera RH, Thongbai B, Wanasinghe DN, Wisitrassameewong K, Tibpromma S, Stadler M (2018) Thailand's amazing diversity: up to $96 \%$ of fungi in northern Thailand are novel. Fungal Diversity 93(1): 215-239. https://doi.org/10.1007/s13225018-0415-7

Hyde KD, Xu J, Rapior S, Jeewon R, Lumyong S, Niego AGT, Abeywickrama PD, Aluthmuhandiram JV, Brahamanage RS, Brooks S, et al. (2019) The amazing potential of fungi: 50 ways we can exploit fungi industrially. Fungal Diversity: 1-136. https://doi.org/10.1007/ s13225-019-00430-9

Jeewon R, Hyde KD (2016) Establishing species boundaries and new taxa among fungi: recommendations to resolve taxonomic ambiguities. Mycosphere 7(11): 1669-1677. https://doi. org/10.5943/mycosphere/7/11/4

Katoh K, Rozewicki J, Yamada KD (2017) MAFFT online service: multiple sequence alignment, interactive sequence choice and visualization. Briefings in Bioinformatics: bbx108. https://doi.org/10.1093/bib/bbx108

Kouvelis VN, Sialakouma A, Typas MA (2008) Mitochondrial gene sequences alone or combined with ITS region sequences provide firm molecular criteria for the classification of Lecanicillium species. Mycological Research 112(7): 829-844. https://doi.org/10.1016/j. mycres.2008.01.016

Kuraku S, Zmasek CM, Nishimura O, Katoh K (2013) aLeaves facilitates on-demand exploration of metazoan gene family trees on MAFFT sequence alignment server with enhanced interactivity. Nucleic Acids Research 41(W1): 22-28. https://doi.org/10.1093/nar/gkt389 
Liang X, Nong XH, Huang ZH, Qi SH (2017) Antifungal and antiviral cyclic peptides from the deep-sea-derived fungus Simplicillium obclavatum EIODSF 020. Journal of Agricultural and Food Chemistry 65(25): 5114-5121. https://doi.org/10.1021/acs.jafc.7b01238

Liang X, Zhang XY, Nong XH, Wang J, Huang ZH, Qi SH (2016) Eight linear peptides from the deep-sea-derived fungus Simplicillium obclavatum EIODSF 020. Tetrahedron 72(22): 3092-3097. https://doi.org/10.1016/j.tet.2016.04.032

Liu F, Cai L (2012) Morphological and molecular characterization of a novel species of Simplicillium from China. Cryptogamie Mycologie 33(2): 137-144. https://doi.org/10.7872/ crym.v33.iss 2.2012.137

Luyen VT (2017) Identification of the entomopathogenic fungi sample DL0069 by combination of morphological and molecular phylogenetic analyses. Vietnam Journal of Science and Technology 55(1A): 117-123. https://doi.org/10.15625/2525-2518/55/1A/12388

Maharachchikumbura SSN, Hyde KD, Jones EBG, McKenzie EHC, Bhat JD, Dayarathne MC, Huang SK, Norphanphoun C, Senanayake IC, Perera RH, Shang QJ, Xiao Y, D'souza MJ, Hongsanan S, Jayawardena RS, Daranagama DA, Konta S, Goonasekara ID, Zhuang WY, Jeewon R, Phillips AJL, Abdel-Wahab MA, Al-Sadi AM, Bahkali AH, Boonmee S, Boonyuen N, Cheewangkoon R, Dissanayake AJ, Kang J, Li QR, Liu JK, Liu XZ, Liu ZY, Luangsa-ard JJ, Pang KL, Phookamsak R, Promputtha I, Suetrong S, Stadler M, Wen T, Wijayawardene NN (2016) Families of Sordariomycetes. Fungal Diversity 79(1): 1-317. https://doi.org/10.1007/s13225-016-0369-6

Mccredden M (2016) Anchors away: The susceptibility and response to infection between native and co-introduced fishes to the alien anchor worm Lernaea cyprinacea. Doctoral dissertation, Murdoch University. https://researchrepository.murdoch.edu.au/id/eprint/35123/

Miller RE, Blair PD (2009) Input-output analysis: foundations and extensions. Cambridge University Press, Cambridge. https://doi.org/10.1017/CBO9780511626982

Nonaka K, Kaifuchi S, Ōmura S, Masuma R (2013) Five new Simplicillium species (Cordycipitaceae) from soils in Tokyo, Japan. Mycoscience 54(1): 42-53. https://doi.org/10.1016/j. myc.2012.07.002

Nylander JAA, Wilgenbusch JC, Warren DL, Swofford DL (2008) AWTY (are we there yet?): a system for graphical exploration of MCMC convergence in Bayesian phylogenetics. Bioinformatics 24(4): 581-583. https://doi.org/10.1093/bioinformatics/btm388

Rambaut A (2006) FigTree. Tree figure drawing tool version 1.3.1. Institute of Evolutionary Biology, University of Edinburgh.

Rannala B, Yang ZH (1996) Probability distribution of molecular evolutionary trees: a new method of phylogenetic inference. Journal of Molecular Evolution 43(3): 304-311. https://doi.org/10.1007/BF02338839

Ronquist F, Huelsenbeck JP (2003) MrBayes 3: Bayesian phylogenetic inference under mixed models. Bioinformatics 19(12): 1572-1574. https://doi.org/10.1093/bioinformatics/btg180

Roy S, Dutta T, Sarkar TS, Ghosh S (2013) Novel xylanases from Simplicillium obclavatum MTCC 9604: comparative analysis of production, purification and characterization of enzyme from submerged and solid state fermentation. SpringerPlus 2(1): 382. https://doi. org/10.1186/2193-1801-2-382 
Scopel M, de Santos O, Frasson AP, Abraham WR, Tasca T, Henriques AT, Macedo AJ (2013) Anti-Trichomonas vaginalis activity of marine-associated fungi from the south Brazilian coast. Experimental Parasitology 133(2): 211-216. https://doi.org/10.1016/j.exppara.2012.11.006

Shin TS, Yu NH, Lee J, Choi GJ, Kim JC, Shin CS (2017) Development of a Biofungicide Using a Mycoparasitic Fungus Simplicillium lamellicola BCP and Its Control Efficacy against Gray Mold Diseases of Tomato and Ginseng. The Plant Pathology Journal 33(3): 337-344. https://doi.org/10.5423/PPJ.FT.04.2017.0087

Skaptsov M, Smirnov S, Kutsev M, Uvarova O, Sinitsyna T, Shmakov A, Matsyura A (2017) Pathogenicity of Simplicillium lanosoniveum to Coccus hesperidum. Ukrainian Journal of Ecology 7(4): 689-691. https://doi.org/10.15421/2017_1801

Spatafora JW, Sung GH, Sung JM, Hywel-Jones NL, White Jr JF (2007) Phylogenetic evidence for an animal pathogen origin of ergot and the grass endophytes. Molecular Ecology 16(8): 1701-1711. https://doi.org/10.1111/j.1365-294X.2007.03225.x

Summerbell RC, Gueidan C, Schroers HJ, de Hoog GS, Starink M, Arocha Rosete Y, Guarro J, Scott JA (2011) Acremonium phylogenetic overview and revision of Gliomastix, Sarocladium, and Trichothecium. Studies in Mycology 68: 139-162. https://doi.org/10.3114/ sim.2011.68.06

Sun JZ, Liu XZ, McKenzie EH, Jeewon R, Liu KJ, Zhang XL, Zhao Q, Hyde KD (2019) Fungicolous fungi: terminology, diversity, distribution, evolution, and species checklist. Fungal Diversity 95(1): 337-430. https://doi.org/10.1007/s13225-019-00422-9

Sung GH, Spatafora JW, Zare R, Hodge KT, Gams W (2001). A revision of Verticillium sect. Prostrata. II. Phylogenetic analyses of SSU and LSU nuclear rDNA sequences from anamorphs and teleomorphs of the Clavicipitaceae. Nova Hedwigia 72: 311-328.

Sung GH, Hywe-ljones NL, Sung JM, Luangsa-ard JJ, Shrestha B, Spatafora JW (2007) Phylogenetic classification of Cordyceps and the clavicipitaceous fungi. Studies in Mycology 57: 5-59. https://doi.org/10.3114/sim.2007.57.01

Supaphon P, Phongpaichit S, Rukachaisirikul V, Sakayaroj J (2014) Diversity and antimicrobial activity of endophytic fungi isolated from the seagrass Enhalus acoroides. Indian Journal of Geo-Marine Sciences 43: 785-797. http://nopr.niscair.res.in/handle/123456789/28764

Swofford DL (2002) PAUP: phylogenetic analysis using parsimony (and other methods), version 4. Sinauer, Sunderland, MA.

Takata K, Iwatsuki M, Yamamoto T, Shirahata T, Nonaka K, Masuma R, Hayakawa Y, Hanaki H, Kobayashi Y, Petersson GA, Ōmura S, Shiomi K (2013) Aogacillins A and B produced by Simplicillium sp. FKI-5985: new circumventors of arbekacin resistance in MRSA. Organic Letters 15(18): 4678-4681. https://doi.org/10.1021/ol401975z

Wang N, Xie YP, Fan JH (2016) Pathogenicity of Simplicillium lanosoniveum TYL001 isolated from Pseudaulacaspis pentagona. Mycosystema 35(5): 559-568. https://doi.org/10.13346/j. mycosystema. 150182

Ward N, Schneider RW, Aime MC (2011) Colonization of soybean rust sori by Simplicillium lanosoniveum. Fungal Ecology 4(5): 303-308. https://doi.org/10.1016/j.funeco.2011.03.008 
Ward NA, Robertson CL, Chanda AK, Schneider RW (2012) Effects of Simplicillium lanosoniveum on Phakopsora pachyrhizi, the soybean rust pathogen, and its use as a biological control agent. Phytopathology 102(8): 749-760. https://doi.org/10.1094/PHYTO-01-11-0031

Wei DP, Wanasinghe DN, Chaiwat TA, Hyde KD (2018) Lecanicillium uredinophilum known from rusts, also occurs on animal hosts with chitinous bodies. Asian Journal of Mycology 1: 63-73. https://doi.org/10.5943/ajom/1/1/5

White TJ, Bruns T, Lee S, Taylor J (1990) Amplification and direct sequencing of fungal ribosomal RNA genes for phylogenetics In: Innis MA, Gelfand DH, Sninsky JJ, White TJ (Eds) PCR protocols: a guide to methods and applications. PCR protocols: a guide to methods and applications. Academic Press, New York, 315-322. https://doi.org/10.1016/ B978-0-12-372180-8.50042-1

Wijayawardene NN, Hyde KD, Lumbsch HT, Liu JK, Maharachchikumbura SSN, Ekanayaka AH, Tian Q, Phookamsak R (2018) Outline of Ascomycota: 2017. Fungal Diversity 88(1): 167-263. https://doi.org/10.1007/s13225-018-0394-8

Xing XY, Chen JY, Dong QL, Guan RJ, Yan SY (2016) Optimization and kinetics analyses of exopolysaccharide production by Simplicillium lanosoniveum. Science and Technology of Food Industry 37(16): 185-191. https://doi.org/10.13386/j.issn1002-0306.2016.18.027

Yan BF, Fang ST, Li WZ, Liu SJ, Wang JH, Xia CH (2015) A new minor diketopiperazine from the sponge-derived fungus Simplicillium sp. YZ-11. Natural Product Research 29(21): 2013-2017. https://doi.org/10.1080/14786419.2015.1027890

Yu YT, He SH, Zhao QM (2013) Isolation and identification of matrine-producing fungal endophytes from Sophora alopecuroides in Ningxia. Scientia Agricultura Sinica 46(13): 2643-2654. https://doi.org/10.3864/j.issn.0578-1752.2013.13.003

Zare R, Gams W (2001) A revision of Verticillium section Prostrata. IV. The genera Lecanicillium and Simplicillium gen. nov. Nova Hedwigia 73: 1-50.

Zare R, Gams W (2008) A revision of the Verticillium fungicola species complex and its affinity with the genus Lecanicillium. Mycological Research 112(7): 811-824. https://doi. org/10.1016/j.mycres.2008.01.019

Zare R, Gams W, Culham A (2000) A revision of Verticillium sect. Prostrata. I. Phylogenetic studies using ITS sequences. Nova Hedwigia 71: 465-480.

Zhang ZF, Liu F, Zhou X, Liu XZ, Liu SJ, Cai L (2017) Culturable mycobiota from Karst caves in China, with descriptions of 20 new species. Persoonia 39: 1-31. https://doi. org/10.3767/persoonia.2017.39.01

Zhao D, Liu B, Li LY, Zhu XF, Wang YY, Wang JQ, Duan YX, Chen LJ (2013) Simplicillium chinense: a biological control agent against plant parasitic nematodes. Biocontrol Science and Technology 23(8): 980-986. https://doi.org/10.1080/09583157.2013.809514

Zhaxybayeva O, Gogarten JP (2002) Bootstrap, Bayesian probability and maximum likelihood mapping: exploring new tools for comparative genome analyses. BMC Genomics 3(1): 4-19. https://doi.org/10.1186/1471-2164-3-4 